
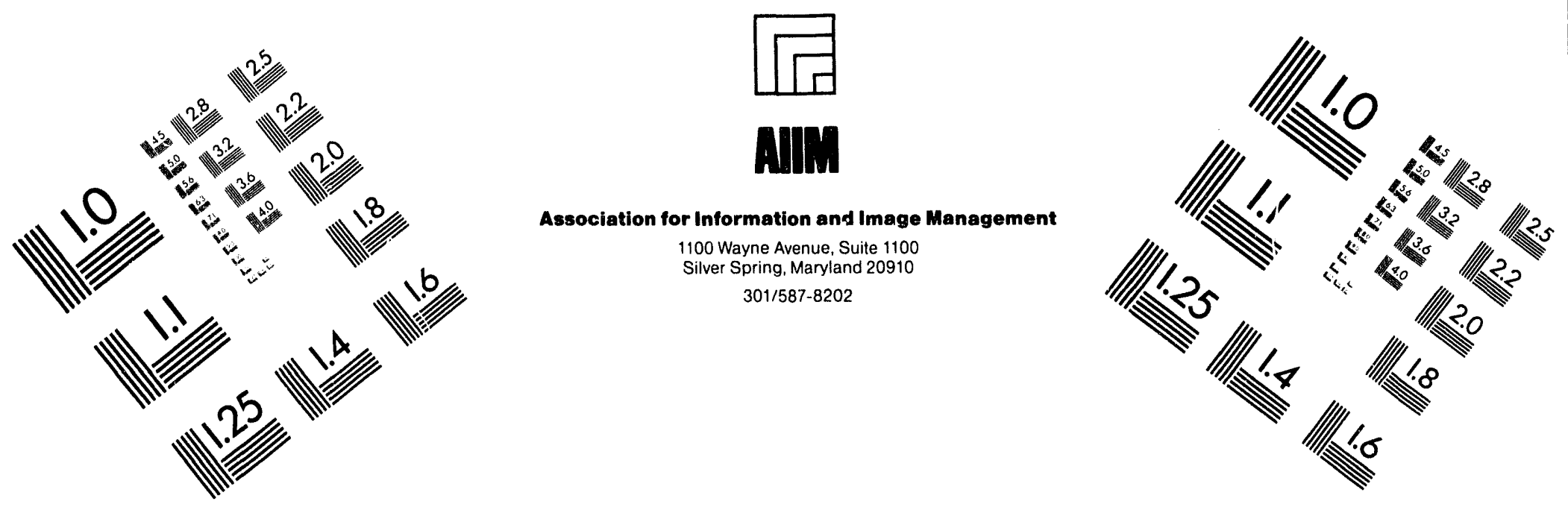

Centimeter

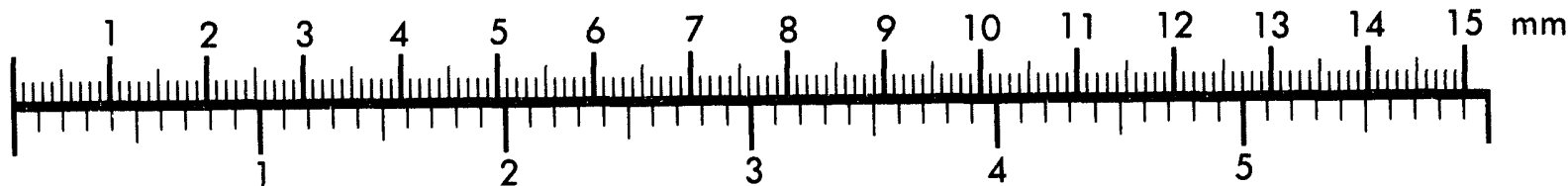

Inches
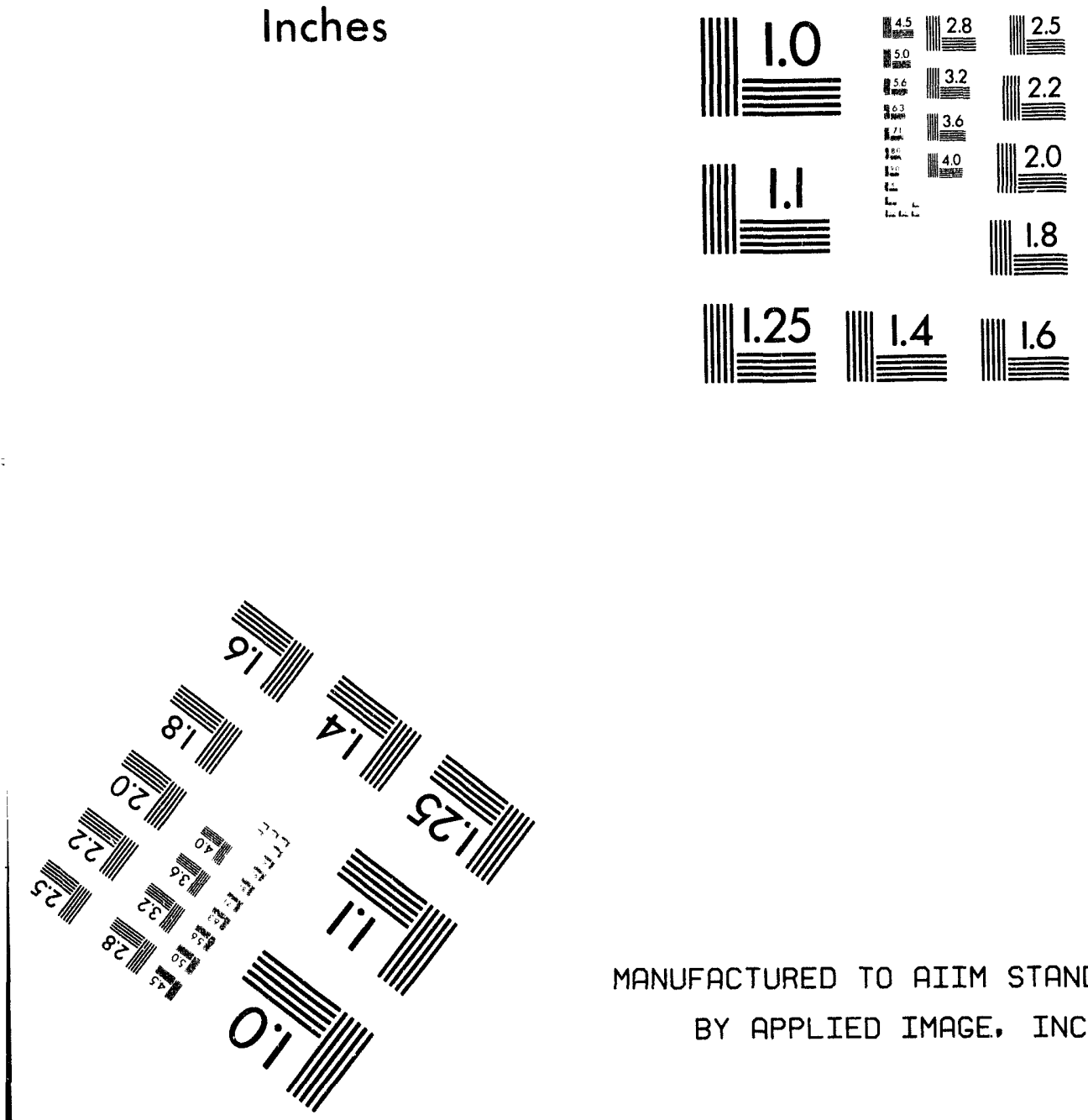

MANUFACTURED TO AIIM STANDARDS

BY APPLIED IMAGE. INC.

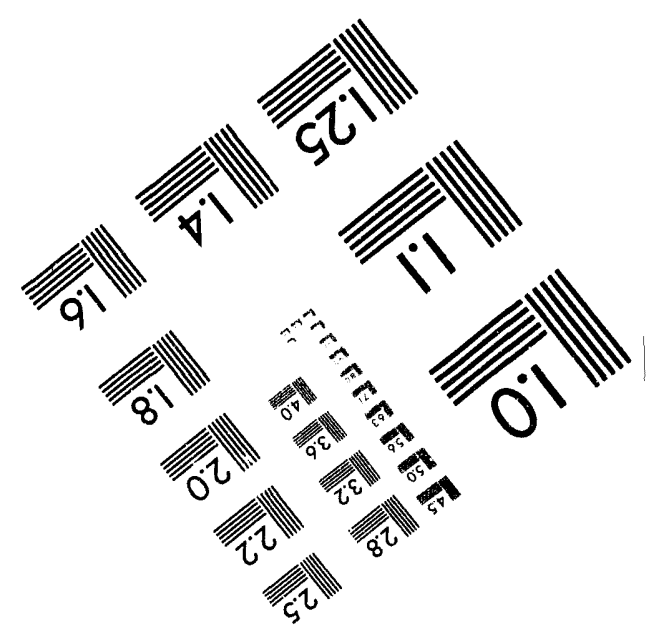



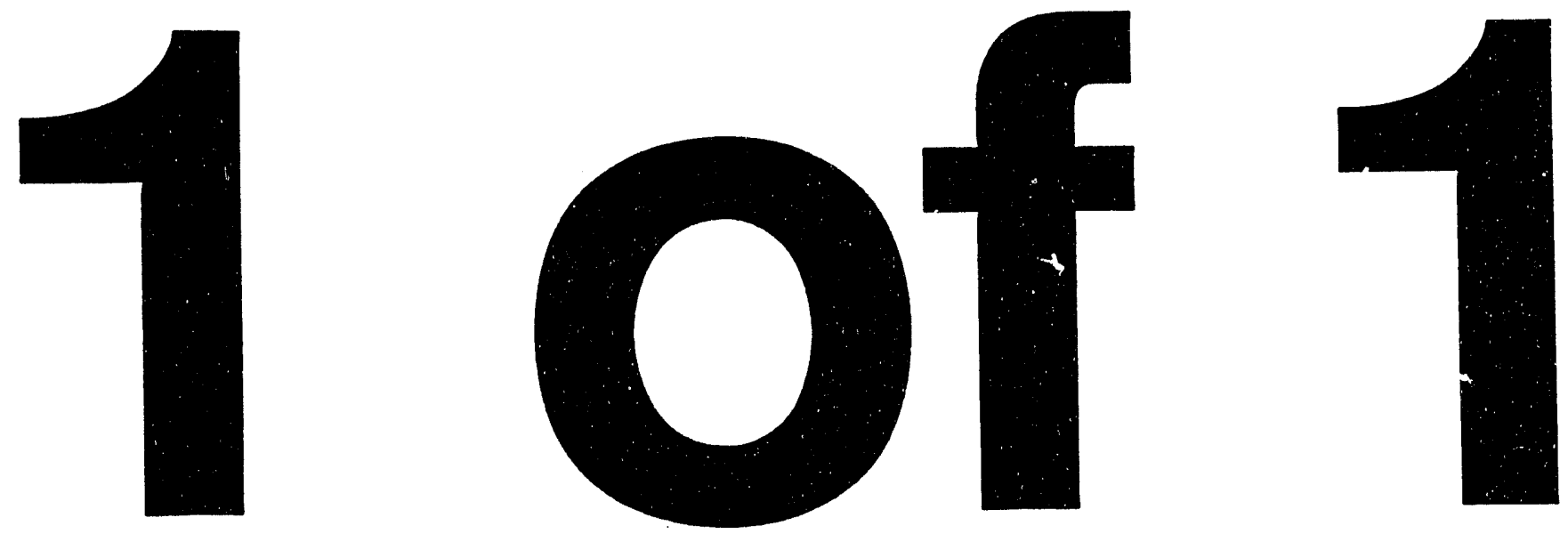


\title{
Coolside Waste Management Research
}

\author{
RECEIVED \\ AU6 29 1994 \\ OSTI
}

Contract No: DE-AC21-91MC28162

Quarterly Progress Report

Report Period: January 1, 1994 to March 31, 1994

\section{DISCLAIMER}

This report was prepared as an account of work sponsored by an agency of the United States Government. Neither the United States Government nor any agency thereof, nor any of their employees, makes any warranty, express or implied, or assumes any legal liability or responsibility for the accuracy, completeness, or usefulness of any information, apparatus, product, or process disclosed, or represents that its use would not infringe privately owned rights. Reference herein to any specific commercial product, process, or service by trade name, trademark, manufacturer, or otherwise does not necessarily constitute or imply its endorsement, recommendation, or favoring by the United States Government or any agency thereof. The views and opinions of authors expressed herein do not necessarily state or reflect those of the United States Government or any agency thereof.

Center for Applied Energy Research University of Kentucky 3572 Iron Works Pike

Lexington, KY 40511-8433 


\title{
COOLSIDE WASTE MANAGEMENT RESEARCH \\ Technical Progress Report \\ Contract No: DE-AC21-91MC28162 \\ Report Period: January 1, 1994 to January 31, 1994
}

\begin{abstract}
Statement of Project Objectives
Produce sufficient information on the physical and chemical nature of Coolside waste to design and construct physically stable and environmentally safe landfills.
\end{abstract}

\section{Summary of Progress for Period}

Work was initiated to determine if dry-FBC material could be used as a soil stabilizing material. Samples were run at a variety of mixes and the strength of the soil was found to be substantially improved. The addition of only $8 \%$ FBC material was found to more than dobule the load bearing capacity of the soil.

Ettringite has been added to the WATEQ thermodynamics data base. As all data has been collected for the laboratory column lysimeters, WATEQ runs were made for all columns. Data extracted for each column leachate collection include concentrations of 43 aqueous species, 71 mineral species which appear to approach saturation levels, and various other indicators such as ionic strength, $\mathrm{CO}_{2}$ partial pressure and species activities. This data, in combination with the leachate analytical data, are being examined to infer chemistry controlling leachate behavior.

Coolside waste is composed of metal oxide furnace products with the addition of gypsum/anhydrite $\left(\mathrm{CaSO}_{4}\right)$, portlandite $\left(\mathrm{Ca}(\mathrm{OH})_{2}\right)$, dolomite $\left(\mathrm{CaMg}\left(\mathrm{CO}_{3}\right)_{2}\right)$ and $\mathrm{Na}$ from sulfur control regimes. Other elements commonly found in coal and coal combustion products are present in trace amounts. Leaching of the waste introduces $\mathrm{H}_{2} \mathrm{O}$ and $\mathrm{CO}_{2}$.

The elements of major importance are $\mathrm{Ca}, \mathrm{S}, \mathrm{C}, \mathrm{Si}$, and $\mathrm{Al}$. In addition, $\mathrm{Mg}$ is important in fly ash leachate. The aqueous species of major importance are $\mathrm{OH}^{\prime}$, silicic acid 
$\left(\mathrm{H}_{4} \mathrm{SiO}_{4}\right)$ and its derivatives, $\mathrm{SO}_{4}{ }^{2-}$, the major element hydroxides and their derivatives, carbonic acid $\left(\mathrm{H}_{2} \mathrm{CO}_{3}\right)$ arid derivatives, and major element carbonates and their derivatives. At this time, the chemistry driving the leachate $\mathrm{pH}$ and composition appears to be:

- Hydrolysis of metal oxides and the resulting high $\mathrm{pH}$. For example, $\mathrm{Ca}(\mathrm{OH})_{2}$ in equilibrium with pure water at $25^{\circ} \mathrm{C}$ has $\mathrm{pH}$ about 12.45 .

- Sulfated dissolution. The analysis of the water indicates the solution to be at or slightly less that caturation with respect to gypsum.

- Carbonate precipitation and lowering of $\mathrm{pH}$. For example, $\mathrm{CaCO}_{3}$ in equilibrium with pure water (no excess $\mathrm{CO}_{2}$ ) has $\mathrm{pH}$ about 10 . This will continue untill equilibrium with the available $\mathrm{CO}_{2}$ is achieved. $\mathrm{CaCO}_{3}$ in equilibrium with water at equilibrium with atmospheric $\mathrm{CO}_{2}\left(\mathrm{pCO}_{2} \sim 3.5\right)$ has $\mathrm{pH} \sim 8.4$.

The preliminary investigation previously reported identified 108 WATEQ mineral forms which approached within 5 orders of magnitude of saturation. This list has been refined to about 40 during the current reporting period. The minerals predomnately include oxide, hydroxide, sulfate, silicate and carbonate mineral forms of the major elements $\mathrm{Ca}, \mathrm{Mg}$ and $\mathrm{Al}$, and those of minor elements $\mathrm{Zn}, \mathrm{Cu}, \mathrm{Ni}, \mathrm{Ba}, \mathrm{Mn}$ and $\mathrm{Cd}$.

\section{Phase II, Task 1, Subtask 1.2 Subgrade Stabilization}

Standard moisture-density relations tests were performed on FBC-soil mixtures to determine changes in maximum dry density and optimum moisture content as the percent of FBC increases. Tests were performed at $0,4,8,12$, and 100 percent FBC. Moisture-density relations curves are located in Figure 4. The maximum dry density decreased from $106.8 \mathrm{lbs} / \mathrm{ft}^{3}$ at zero percent FBC to $76.7 \mathrm{lbs} / \mathrm{ft}^{3}$ at one hundred percent FBC and optimum water content increased from 19.4 to 27.8 percent as seen in Figures 1 and 2 and Appendix $A$. The soil used was one with marginal engineering properties (A-7-6, CL, AASHTO and Unified classification, respectively) obtained from Ohio. 


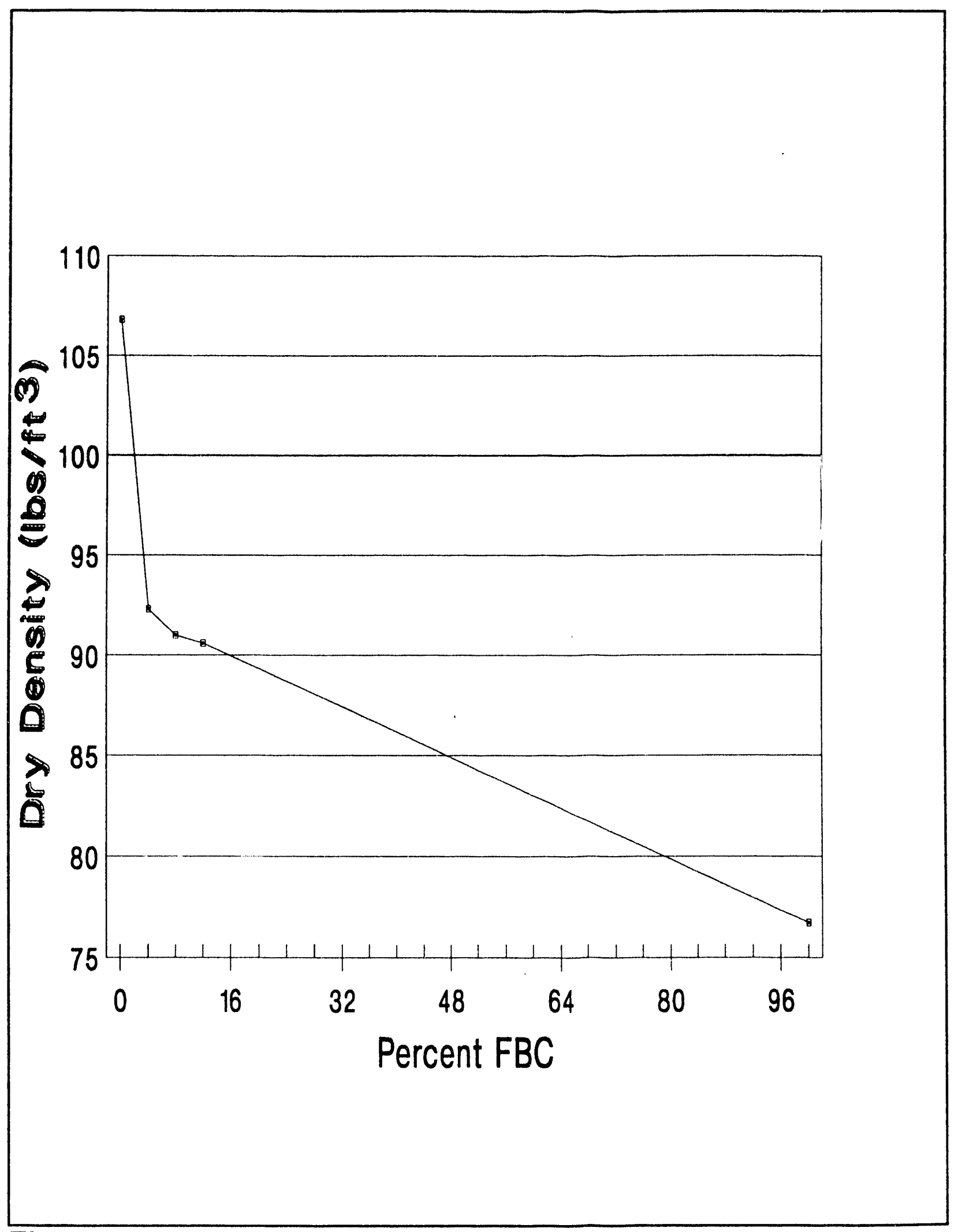

Figure 1. Percent FBC versus Dry Density 


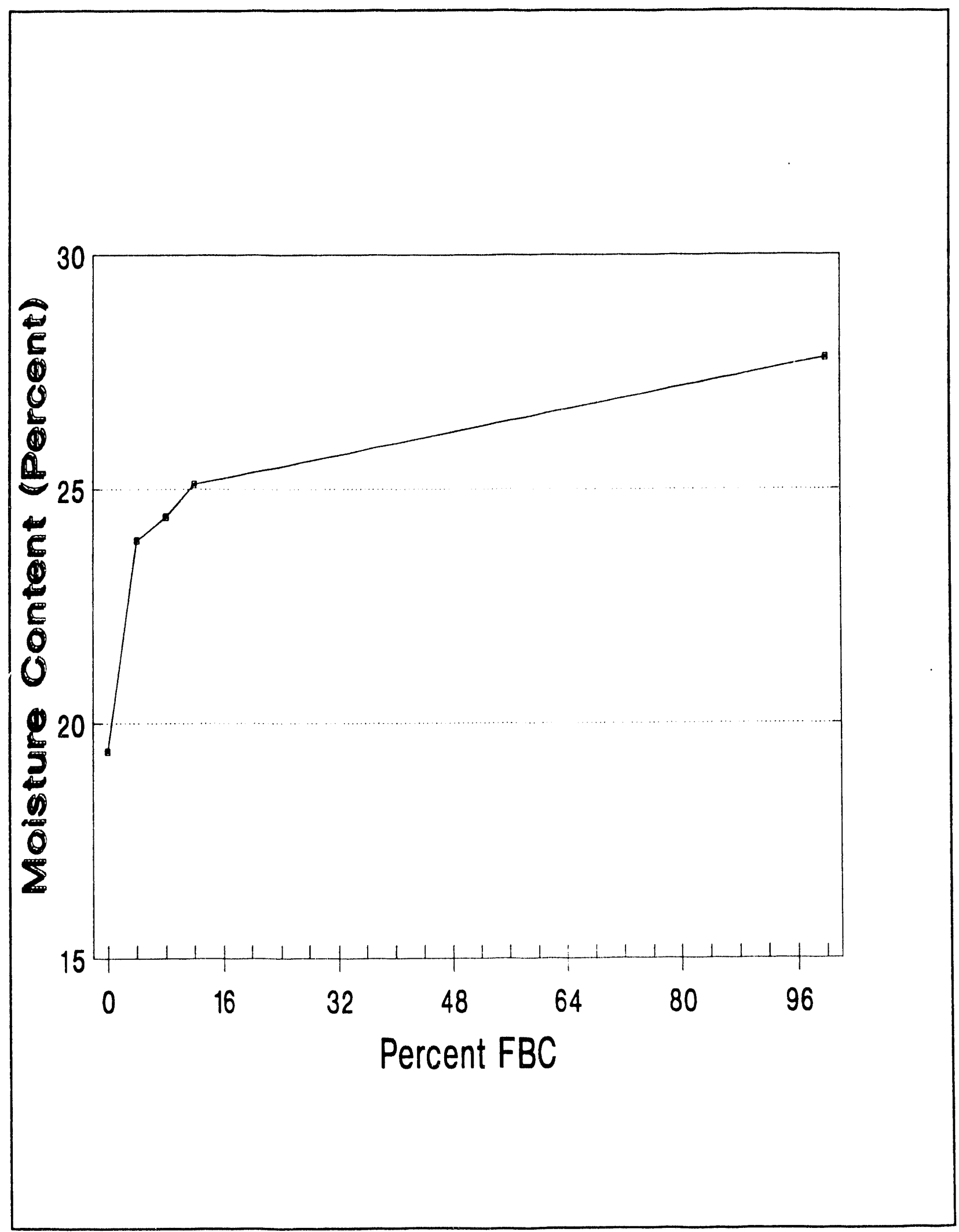

Figure 2. Percent FBC versus Moisture Content. 
Unconfined compressive strength tests were performed to determine if the addition of FBC would result in an increase in this parameter. Samples were remolded, sealed, and aged at room temperature for seven to fourteen days before testing. Strength increased from $21.1 \mathrm{lbs} / \mathrm{in}^{2}$ (O\% FBC) to $330.0 \mathrm{lbs} / \mathrm{in}^{2}$ (100\% FBC aged 14 days) as seen in Figure 3.

\section{Phase I, Task 6 - Data Evaluation}

\section{Thermodynamic Data Base}

The WATEQ program attempts to infer theoretically, given $\mathrm{pH}$ and ionic coricentrations of water-borne ions, the active chemical species and approach to saturation of possible mineral entities through which the water has passed. During the current reporting period, a preliminary selection has been made of species and minerals which may drive leachate chemistry, are driven by the chemistry and may be present in significant amounts, or are the predominant carriers of minor ions of interest. In addition, ettringiite was added to the thermodynamic database for WATEQ.

WATEQ measures mineral approach to equilibrium by comparing the products of the activities of the constituent ions (Ion Activity Product or IAP) with the equilibrium solubility product, specifically, $\log \left(\mid A P / K_{1}\right)$ where $K$, the equilibrium solubility product, is corrected for temperature. A value greater than zero indicates supersaturation. Individual ion activities are the product of the ion concentration and an activity coefficient which attempts to correct for the ionic strength of the solute. The concentrations are determined by an iterative mass and charge balance over the possible species present given the analytical input data of concentrations and $\mathrm{pH}$.

There are enough sources of error inherent in these calculations that measures of approach to equilibrium must not be viewed as absolute indicators of the presence or absence of a particular mineral, or that any equilibrium has been reached. One source of error is the equilibrium solubility product, $K$, for each mineral. The range of 


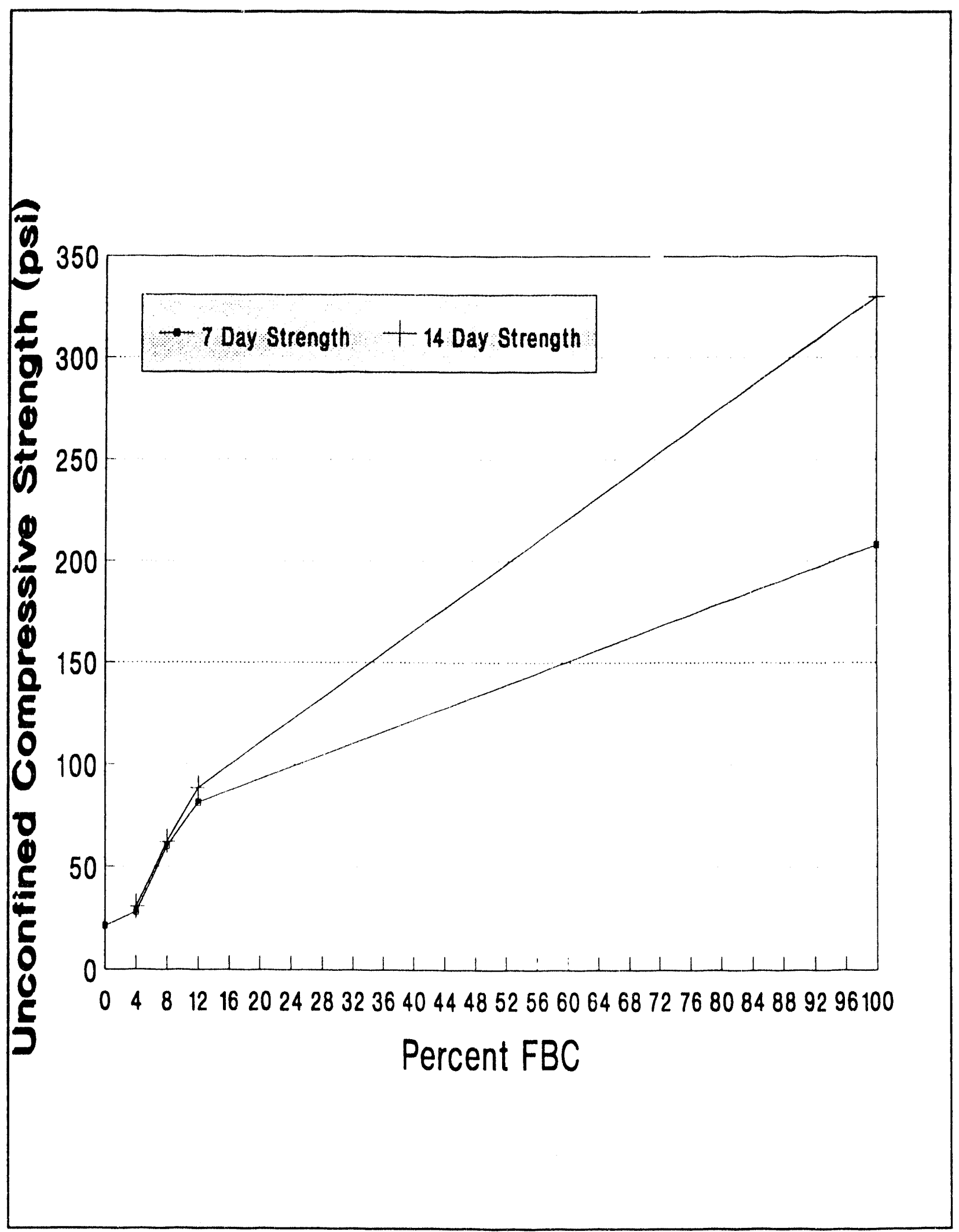

Figure 3. Percent FBC versus Unconfined Compressive Strength. 
solubilities depends on the degree of crystallinity, particle size effects, order-disorder phenonema, defect structures, range of solid solutions, interlayering and meta-stability. For instance, the calcite $\left(\mathrm{CaCO}_{3}\right)$ group consists of calcite plus the substitution in varying amounts of $\mathrm{Mg}, \mathrm{Mn}, \mathrm{Zn}, \mathrm{Fe}$, and $\mathrm{Cd}$ in the matrix for $\mathrm{Ca}$, depending on availability. Thus, formation of calcite may also include magnesite $\left(\mathrm{MgCO}_{3}\right)$, rhodocrosite $\left(\mathrm{MnCO}_{3}\right)$, smithsonite $\left(\mathrm{ZnCO}_{3}\right)$, siderite $\left(\mathrm{FeCO}_{3}\right)$ and otavite $\left(\mathrm{CdCO}_{3}\right)$ as part of the solid solution. These individually do not have equal solubilities. At primary saturation, or thermodynamic equilibrium, the aqueous phase will be undersaturated with respect to the solid components. Conversely, a high degree of supersaturation of the most soluble components will exist at stoichiometric saturation. Other examples exhibiting this behavior include quartz, gibbsite, kaolinite, sepiolite, oxides and hydroxides, feldspars and micas. Additionally, the solid phase initially formed may be meta-stable with respect to the thermodynamically preferred state. For example, calcite is thermodynamically preferred over aragonite, but aragonite may form initially as a very fine solid phase with a disordered lattice and slowly convert to the more stable, relatively inactive, less soluble calcite form. Silica $\left(\mathrm{SiO}_{2}\right)$ forms, anhydrite/gypsum and hydroxides also exhibit this behavior. Another source of error is the determination of the ion activity coefficient over large ranges of ionic strength. In very dilute solutions, the activity coefficient is 1 , so that the ion activity is equal to the molar concentration. As ionic strength increases, the coefficient first increases. This increase in ion activity drives the equilibrium toward formation of the neutral species, resulting in a "salting out" of the solid phase. As the ionic strength increases toward and past one, the activity coefficient may drop below one due to greater ionic association in the solute, driving the equilibrium reaction toward dissolution of the solid phase. For ionic strengths above about 0.5 , the activity coefficients become increasingly uncertain.

The ionic strengths encountered in the Coolside column leachate range from $\sim 0.01$ to 2.5. Representative variation of column leachate ionic strength over time is illustrated in Figure 4. For comparison, the effective ionic strength of a free flowing stream is $\sim 0.01$, groundwater $\sim 0.1$, seawater $\sim 1$. Despite these uncertainties in solubility 


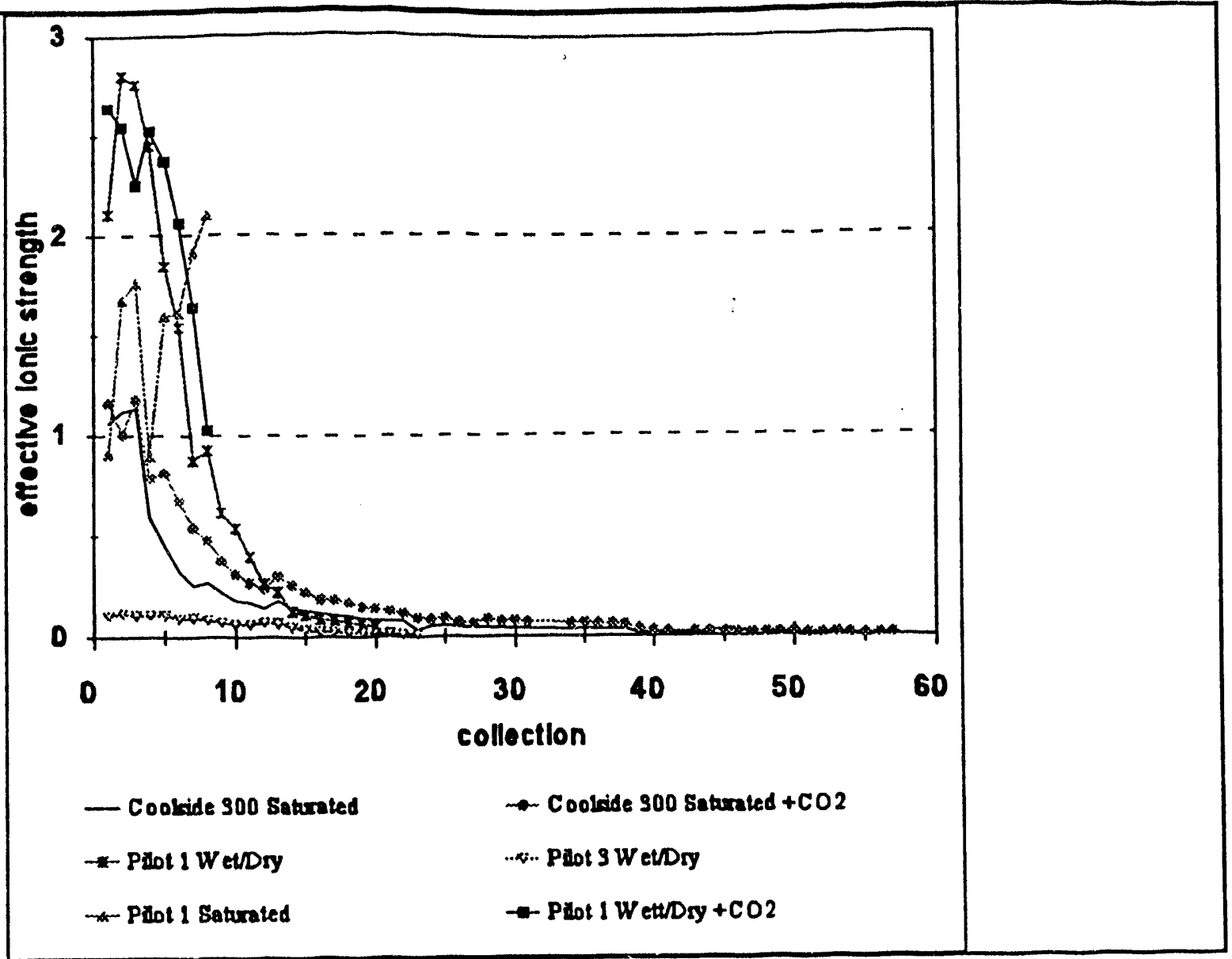

Figure 4. Representative ionic strengths vs time

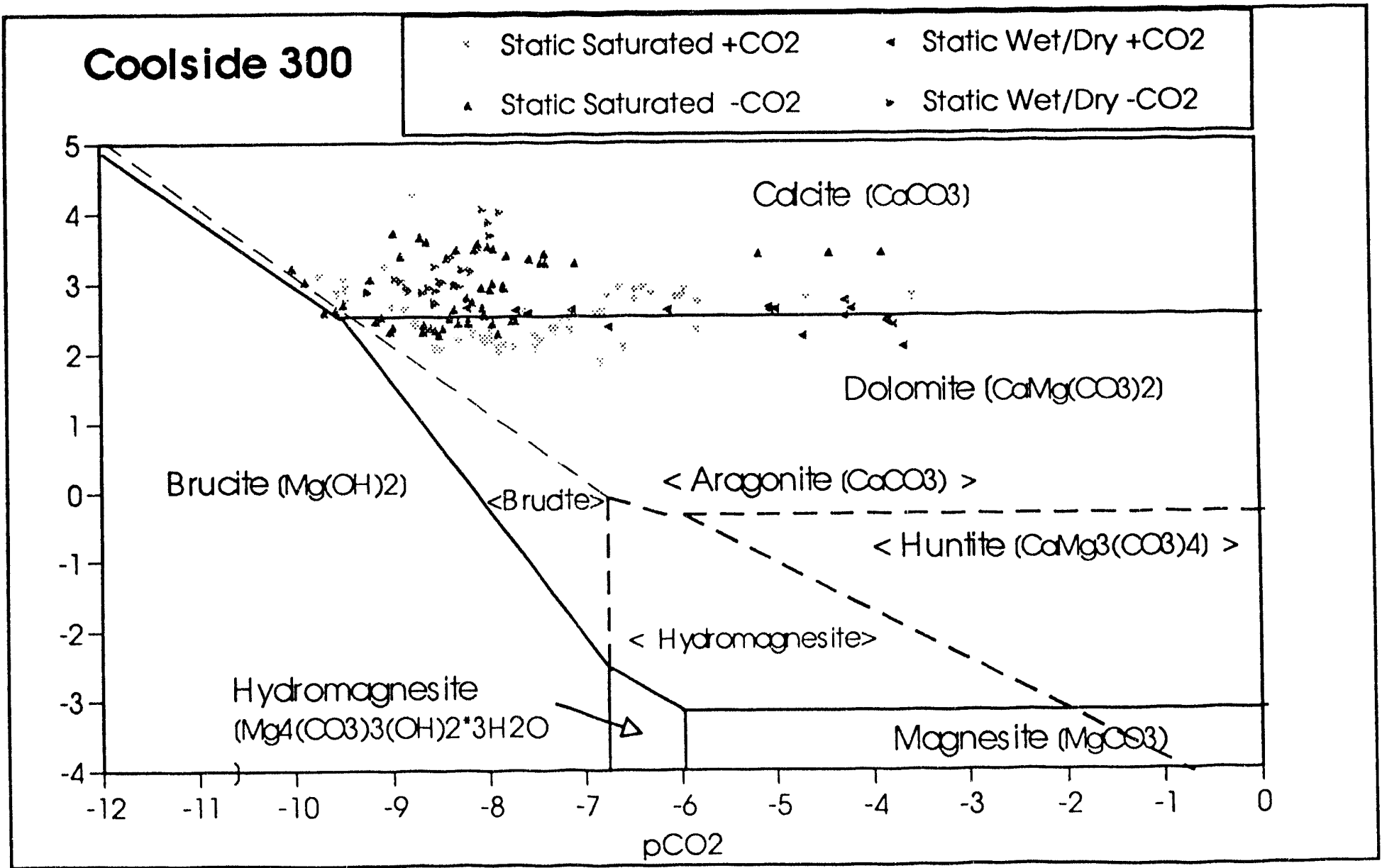

Figure 5. Representative Coolside equilivrium. $\log [(\mathrm{Ca}$ activity $) /(\mathrm{Mg}$ activity $)]$ vs $\log \left(\mathrm{pCO}_{2}\right)$ 
constants and ion activity products, the equilibrium calculations performed are useful as an aid in interpreting observed fact.

\section{Selection of Primary lonic Species}

The major components of coal combustion waste are normally oxides of $\mathrm{Mg}, \mathrm{Na}, \mathrm{Fe}, \mathrm{Ti}$, $\mathrm{Si}, \mathrm{Ca}, \mathrm{K}, \mathrm{P}$, and $\mathrm{Al}$. In addition there are a significant amounts of $\mathrm{Cl}$ and $\mathrm{SO}_{3}$. There are trace amounts of other metals such as $\mathrm{Zn}, \mathrm{Cu}, \mathrm{Ni}, \mathrm{Co}, \mathrm{Cr}, \mathrm{Ba}, \mathrm{V}, \mathrm{As}, \mathrm{B}, \mathrm{V}, \mathrm{Mn}, \mathrm{Sr}$, $\mathrm{Zr}$ and $\mathrm{Cd}$. The Coolside sulfur control regime results in the addition of anhydrite $\left(\mathrm{CaSO}_{4}\right) /$ gypsum $\left(\mathrm{CaSO}_{4}{ }^{2} \mathrm{H}_{2} \mathrm{O}\right)$, portlandite $\left(\mathrm{Ca}(\mathrm{OH})_{2}\right)$, dolomite $\left(\mathrm{CaMg}\left(\mathrm{CO}_{3}\right)_{2}\right)$ and, in some cases, $\mathrm{Na}$. Co, $\mathrm{Cr}, \mathrm{Mo}, \mathrm{Ti}, \mathrm{Zr}, \mathrm{V}$ and Se are given little or no treatment in WATEQ, so will not be considered further. Upon leaching, it would be expected that hydrolysis would result in the release of the metal ion and $\mathrm{OH}^{-}$into solution, resulting in a highly alkaline solute. Free trivalent ions, such as those of $\mathrm{Al}, \mathrm{Fe}$ and $\mathrm{Mn}$, are not important, as they tend to form under conditions of low ionic strengths and high acidity. With the exception of $\mathrm{Al}^{+3}$, they tend to form insoluble hydroxides. Therefore, $\mathrm{Al}(\mathrm{OH})_{3}{ }^{0}$ and $\mathrm{Al}(\mathrm{OH})_{4}{ }^{\circ}$ are expected, as are divalent $\mathrm{Ca}, \mathrm{Mg}, \mathrm{Zn}, \mathrm{Cu}$ and $\mathrm{Ba}$, monovalent $\mathrm{Na}$ and $\mathrm{K}$ ions, and $\mathrm{OH}$. The leaching water is generally in equilibrium with a $\mathrm{CO}_{2}$ source. This source may be the atmosphere or soil. The partial pressure of $\mathrm{CO}_{2}\left(\mathrm{pCO}_{2}\right)$ in water in equilibrium with the atmosphere is approximately $10^{-3.5}$. The $\mathrm{pCO}_{2}$ in soil may be much higher due to organic respiration. It is expected that leaching will introduce significant amounts of $\mathrm{CO}_{2}$ into the solute. The steps in $\mathrm{CO}_{2}$ hydration are

$$
\begin{aligned}
& \text { 1: } \mathrm{CO}_{2}+\mathrm{H}_{2} \mathrm{O}=\mathrm{H}_{2} \mathrm{CO}_{3}^{0} \\
& \text { 2: } \mathrm{H}_{2} \mathrm{CO}_{3}^{0}+\mathrm{H}_{2} \mathrm{O}=\mathrm{HCO}_{3}^{-}+\mathrm{H}_{3} \mathrm{O}^{+} \\
& \text {3: } \mathrm{CO}_{2}+\mathrm{OH}^{-}=\mathrm{HCO}_{3}^{-}
\end{aligned}
$$

Step 2 is rapid at room temperature, while steps 1 and 3 are slow. At higher $\mathrm{pH}$, however, excess hydroxide increases the relative importance of step 3. At the $\mathrm{pH}$ 's of the leachates, the carbonate ion, $\mathrm{CO}_{3}{ }^{2}$, will be expected to be the dominate form of carbonate present. Quartz $\left(\mathrm{SiO}_{2}\right)$ is slowly acted upon by alkali at room temperature, with long equilibrium time. This reaction rate increases rapidly above $\mathrm{pH} 9$ due to 


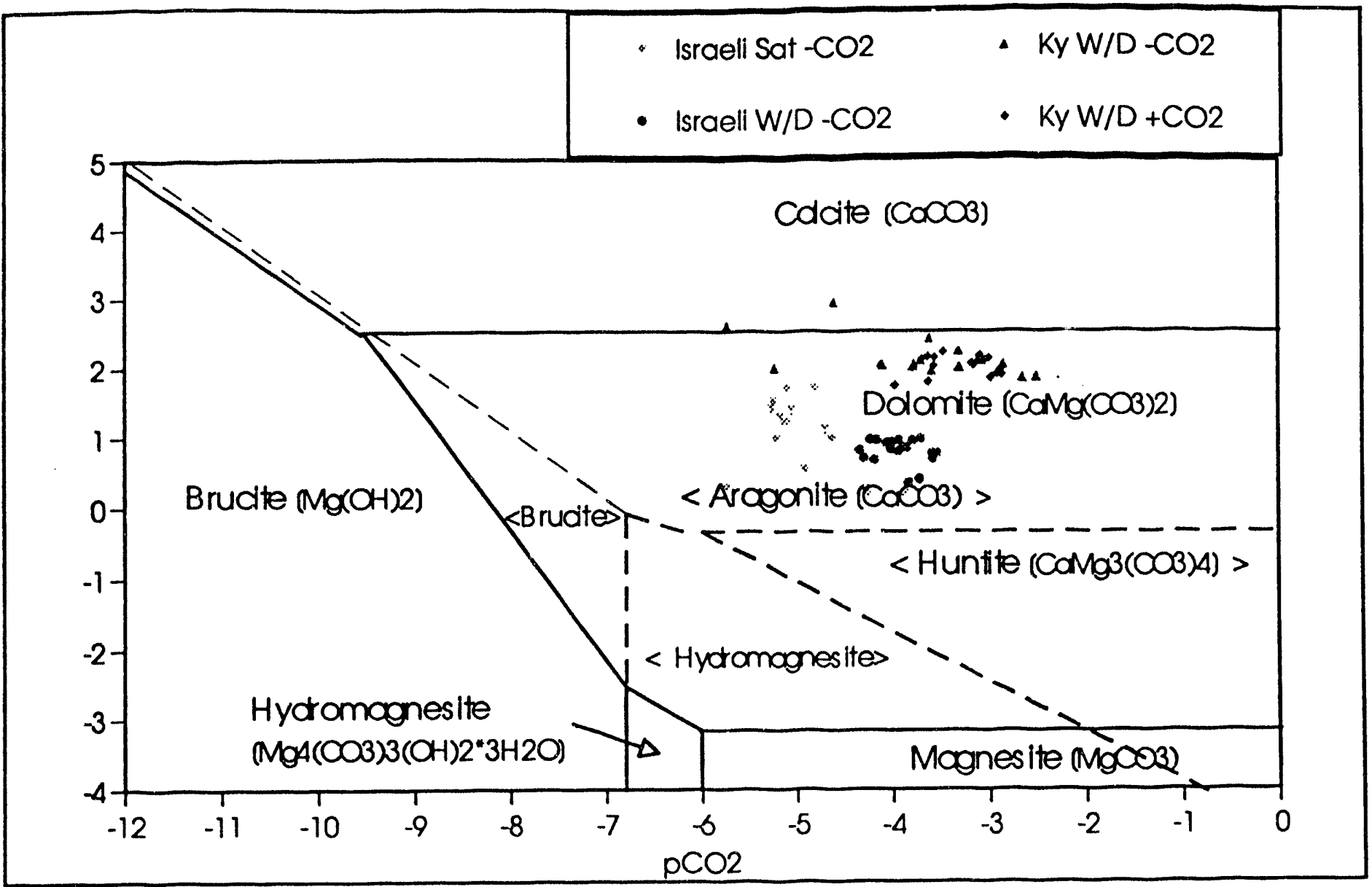

Figure 6. Fly Ash equilibrium. $\log [(\mathrm{Ca}$ activity $) /(\mathrm{Mg}$ activity $)]$ vs $\log \left(\mathrm{pCO} \mathrm{CO}_{2}\right)$

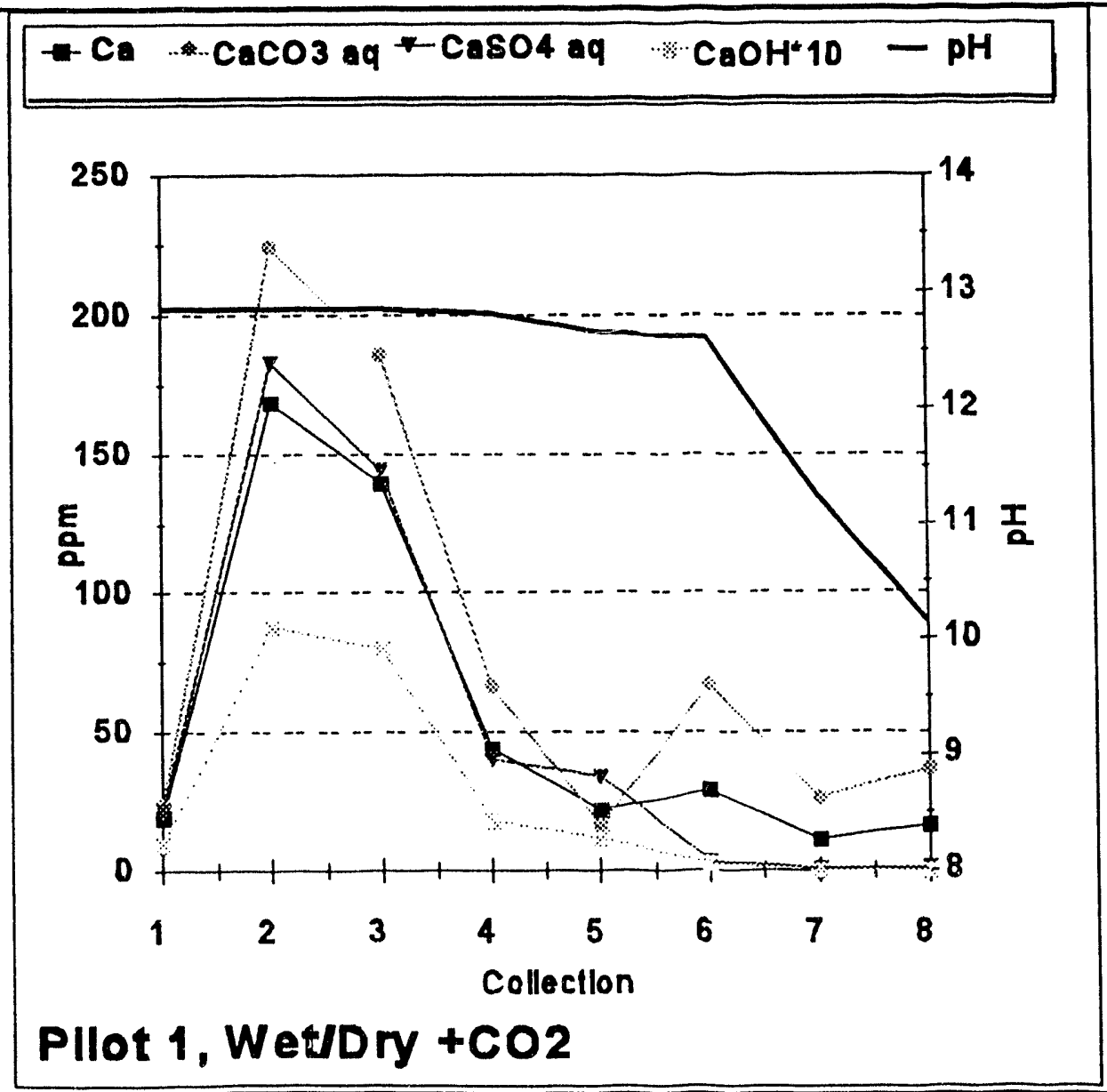

Figure 7. Calcium species concentration, Pilot 1 column 
ionization of silicic acid $\left(\mathrm{H}_{4} \mathrm{SiO}_{4}\right.$ or $\left.\mathrm{Si}(\mathrm{OH})_{4}\right)$ and formation of monomeric or multimeric domains, so that $\mathrm{Si}(\mathrm{OH})_{4}{ }^{\circ}$ and $\mathrm{SiO}(\mathrm{OH})_{3}{ }^{\circ}$ are expected. $\mathrm{SO}_{4}{ }^{2 \cdot}$ and $\mathrm{HSO}_{4}{ }^{-}$are expected to be available from the dissolution of anhydrite/gypsum.

Based on these considerations, the foliowing solute species have currently been selected for analysis:

$\mathrm{CO}_{2}$ total, $\mathrm{Al}(\mathrm{OH})_{4} ; \mathrm{Ca}, \mathrm{Cl}_{1} \mathrm{CO}_{3}{ }^{2-}, \mathrm{HCO}_{3} ; \mathrm{Na}, \mathrm{OH}, \mathrm{PO}_{4}{ }^{2}, \mathrm{SiO}_{2}{ }^{\circ}, \mathrm{SO}_{4}{ }^{2-}, \mathrm{Zn}, \mathrm{Al}, \mathrm{H}, \mathrm{K}, \mathrm{Mn}$, $\mathrm{Al}(\mathrm{OH})_{3}{ }_{3}, \mathrm{CaCO}_{3}{ }^{0}, \mathrm{CaHCO}_{3}{ }^{+}, \mathrm{CaOH}^{+}, \mathrm{CaSO}_{4}{ }^{\circ}, \mathrm{CaHSO}_{4}, \mathrm{HCO}_{3}{ }^{\circ}, \mathrm{MgCO}_{3}{ }^{0}, \mathrm{MgHCO}_{3}{ }^{+}$, $\mathrm{MgOH}^{+}, \mathrm{MgSO}_{4}{ }^{\prime}, \mathrm{NaCO}_{3}{ }^{-}, \mathrm{NaHPO}_{4}{ }^{\circ}, \mathrm{NaSO}_{4}^{-}, \mathrm{PbCl}^{+}, \mathrm{PbCO}_{3}{ }^{0}, \mathrm{PbHCO}_{3}{ }^{+}, \mathrm{Pb}(\mathrm{OH})_{4}{ }^{2-}$, $\mathrm{HPO}_{4}{ }^{-}, \mathrm{SiO}_{2}{ }^{0}, \mathrm{Si}(\mathrm{OH})_{4}^{0}, \mathrm{SiO}_{2}(\mathrm{OH})_{2}{ }^{2-}, \mathrm{SO}_{4}{ }^{2-}, \mathrm{ZnCl}^{+}, \mathrm{ZnCO}_{3}{ }^{0}, \mathrm{ZnHCO}_{3}{ }^{+}, \mathrm{ZnOH}^{+}, \mathrm{Zn}(\mathrm{OH})_{4}{ }^{2-}$ , $\mathrm{ZnOHCl}^{\circ}, \mathrm{ZnSO}_{4}{ }^{\circ}$ and $\mathrm{MnCO}_{3}{ }^{\circ}$.

In addition, the following items have also been selected: $\mathrm{pH},-\log \left(\mathrm{pCO}_{2}\right)$, Effective lonic Strength, $\mathrm{aH}_{2} \mathrm{O}$ (activity of water), $-\log (\mathrm{Ca}$ activity) and $\log (\mathrm{Mg}$ activity). It is expected that this list will change as analysis and interpretation continues.

\section{Selection of Primary Mineral Species}

In the previously reported preliminary investigation, WATEQ minerals which approached to within 5 orders of magnitude of saturation were found. The 108 minerals meeting this criteria have been further investigated to select those which may drive leachate chemistry, are driven by the chemistry and may be present in significant amounts, or are the predominant carriers of minor ions of interest. Given the nature of Coolside waste, the characteristics of the oxides are of immediate importance. Of greatest interest are those present in large amounts, i. e., those of $\mathrm{Ca}, \mathrm{Al}, \mathrm{Fe}, \mathrm{K}$, and $\mathrm{Na}$. It is expected that hydrolysis of these oxides will result in free aqueous hydroxides and metal ions, with a resulting high $\mathrm{pH}$. On introduction of atmospheric $\mathrm{CO}_{2}$, metal carbonate precipitation will act to lower $\mathrm{pH}$ to some equilibrium value over some unknown period. The $\mathrm{pH}$ range seen in Coolside leaching roughly corresponds to that of portlandite $\left(\mathrm{Ca}(\mathrm{OH})_{2}\right)$ in equilibrium with pure water (about 12.45) down to calcite 
$\left(\mathrm{CaCO}_{3}\right)$ in equlibrium with water that is in equilibrium with atmospheric $\mathrm{CO}_{2}(\mathrm{pH}$ about 8.4 at $\log \left(\mathrm{pCO}_{2}\right)=-3.5$ ) (Figure 7). The dissolution of silica and gypsum/anhydrite add the possibility of silicate and sulfate mineral formation.

Silica The forms of $\mathrm{SiO}_{2}$ possible are quartz, cristabolite, chalcedony and silica gel. The higher forms, such as tridymite, would naturally convert to the lower forms over time. XRD data show the presence of quartz. Cristabolite is formed under high temperature up to melting and persists in metastable form on cooling, with eventual conversion to quartz. Its highly symmetric, open structure is thermodynamically slightly favored over tridymite and quartz. Chalcedony is a fibrous silica, often occurring in small residues as crusts or cavity filling. It is readily soluble in alkaline solutions. Silica gel is a form favored on formation at STP, most soluble, and ages into poorly crystallized cristabolite. Quartz is most easily recognized by XRD, is the expected initial form, and is least soluble. Inspection of leachate column approach to saturation of the silica members show that quartz most nearly approaches equilibrium, but usually remains below (e.g., Figure 13, other representative approaches to saturation are shown in Figures 8 to 14). If any other form predominated, then quartz would be supersaturated. Its dissolution is expected to supply $\mathrm{SiO}_{2}$ to the solute. Silica formation, if any, would be expected to be of the silica gel dimorph. Quartz has been chose as the silica member of interest.

$\mathrm{Na}$ The initial sodium mineral forms selected, based on approach to equilibrium, were halite $(\mathrm{NaCl})$, nahcolite $\left(\mathrm{NaHCO}_{3}\right)$, trona $\left(\mathrm{Na}_{3} \mathrm{H}\left(\mathrm{CO}_{3}\right)_{2}{ }^{\star} 2 \mathrm{H}_{2} \mathrm{O}\right)$, thermonatrite $\left(\mathrm{Na}_{2} \mathrm{CO}_{3}{ }^{*} \mathrm{H}_{2} \mathrm{O}\right)$, natron $\left(\mathrm{Na}_{2} \mathrm{CO}_{3}{ }^{*} 10 \mathrm{H}_{2} \mathrm{O}\right)$, mirabilite $\left(\mathrm{Na}_{2} \mathrm{SO}_{4}{ }^{*} 10 \mathrm{H}_{2} \mathrm{O}\right)$ and thenardite $\left(\mathrm{Na}_{2} \mathrm{SO}_{4}\right)$. They all show significant degrees of supersaturation. All of these are extremely water soluble, however, and are not expected to be formed. Na may be involved in minor silicate mineral formation mentioned later. It is expected that $\mathrm{Na}$ from oxide dissolution and sodium addition due to sulfur control regimes will be found as free ions in the solute and will be involved in a very minor way in mineral formation. Its major effect on leachate chemistry is in contributing to the ionic strength of the 


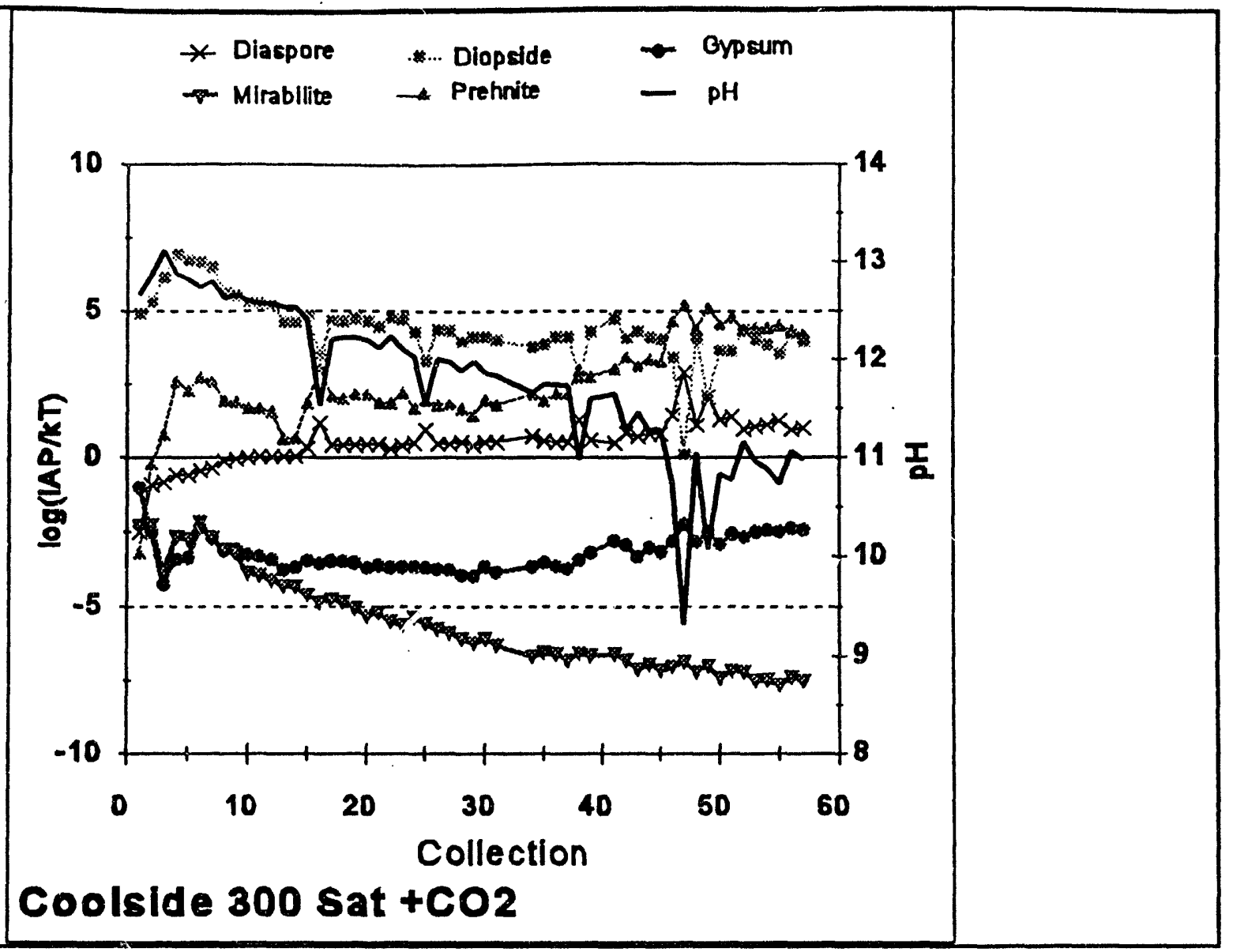

Figure 8.

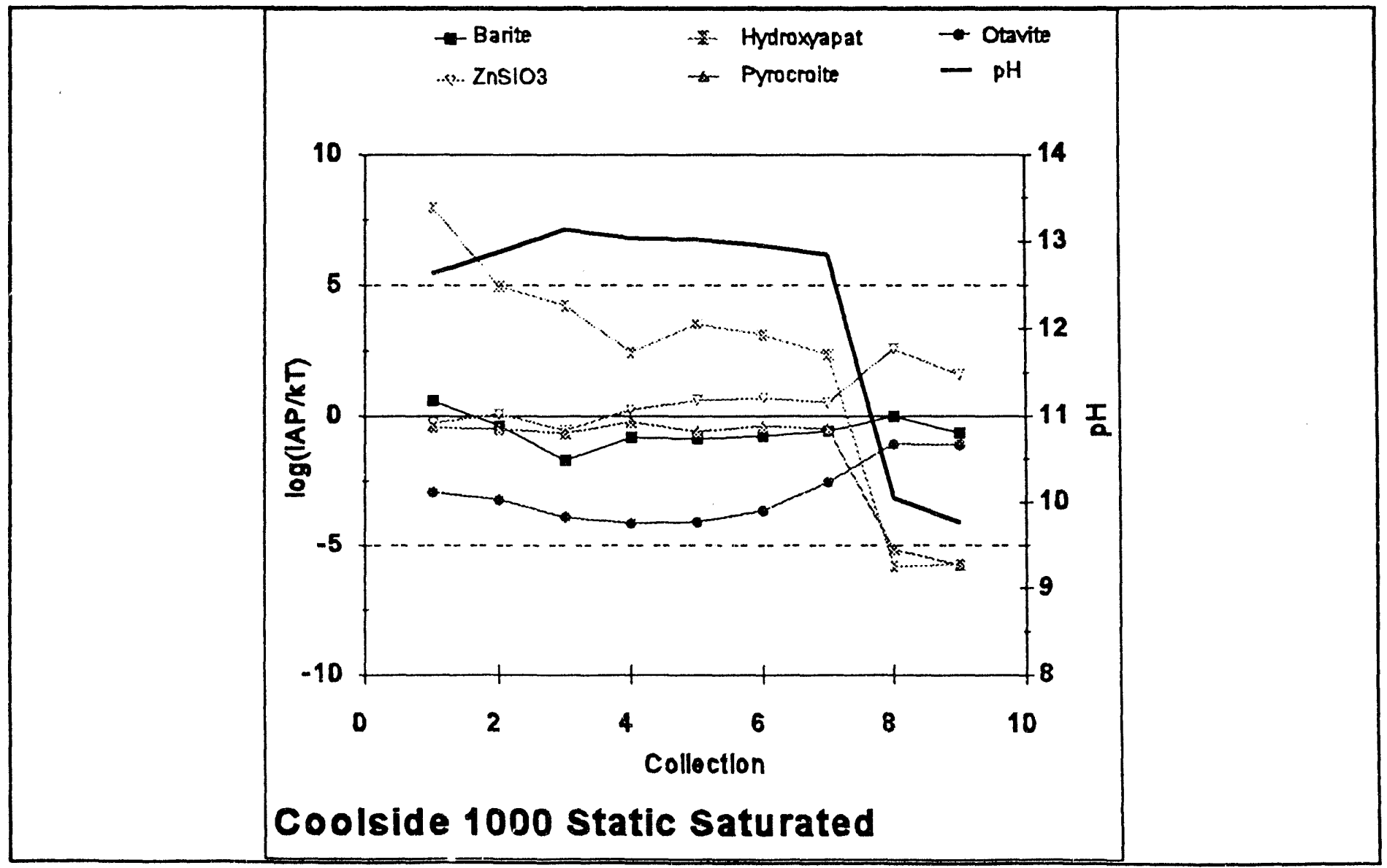

Figure 9. 


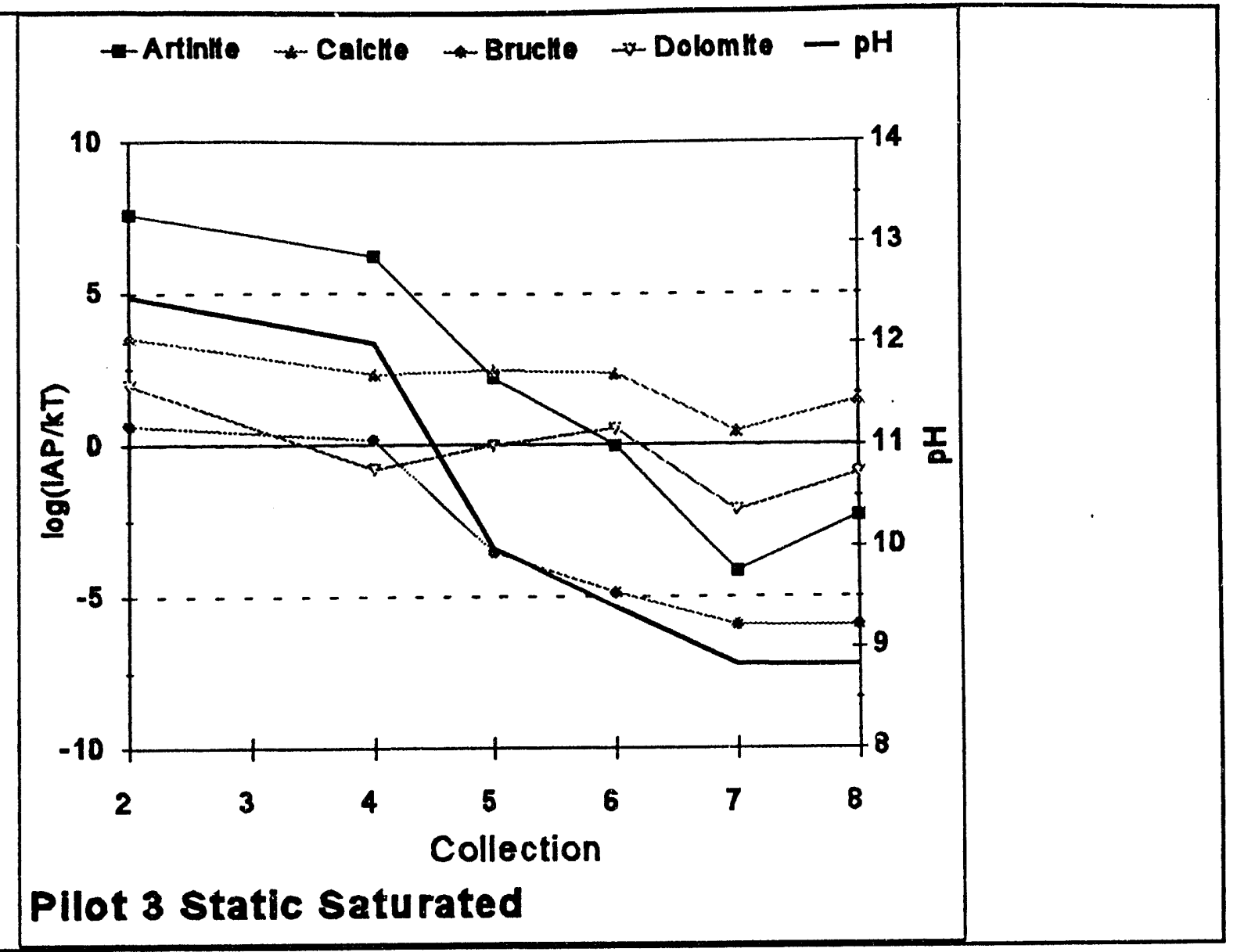

Figure 10.

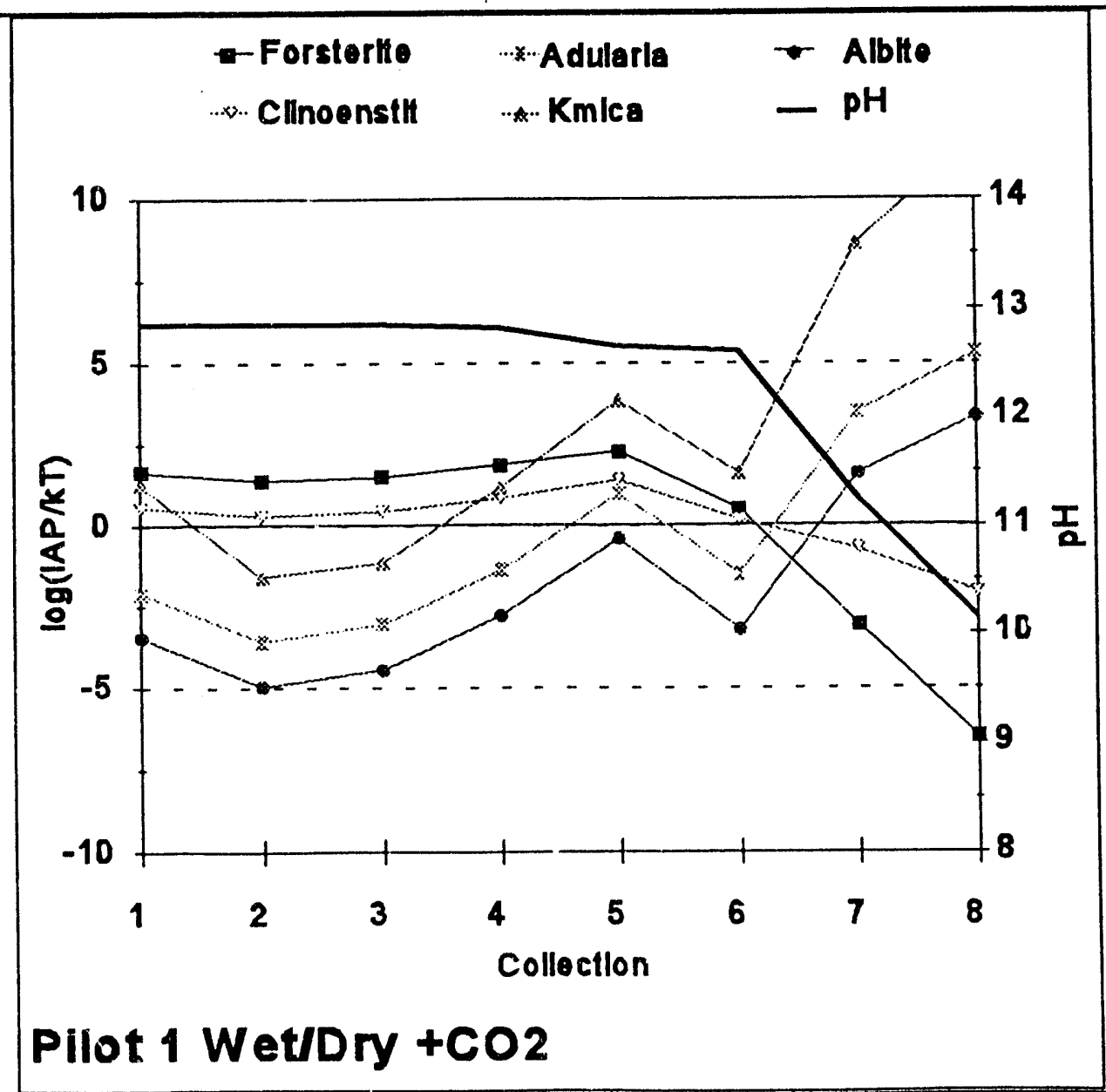

Figure 11. 


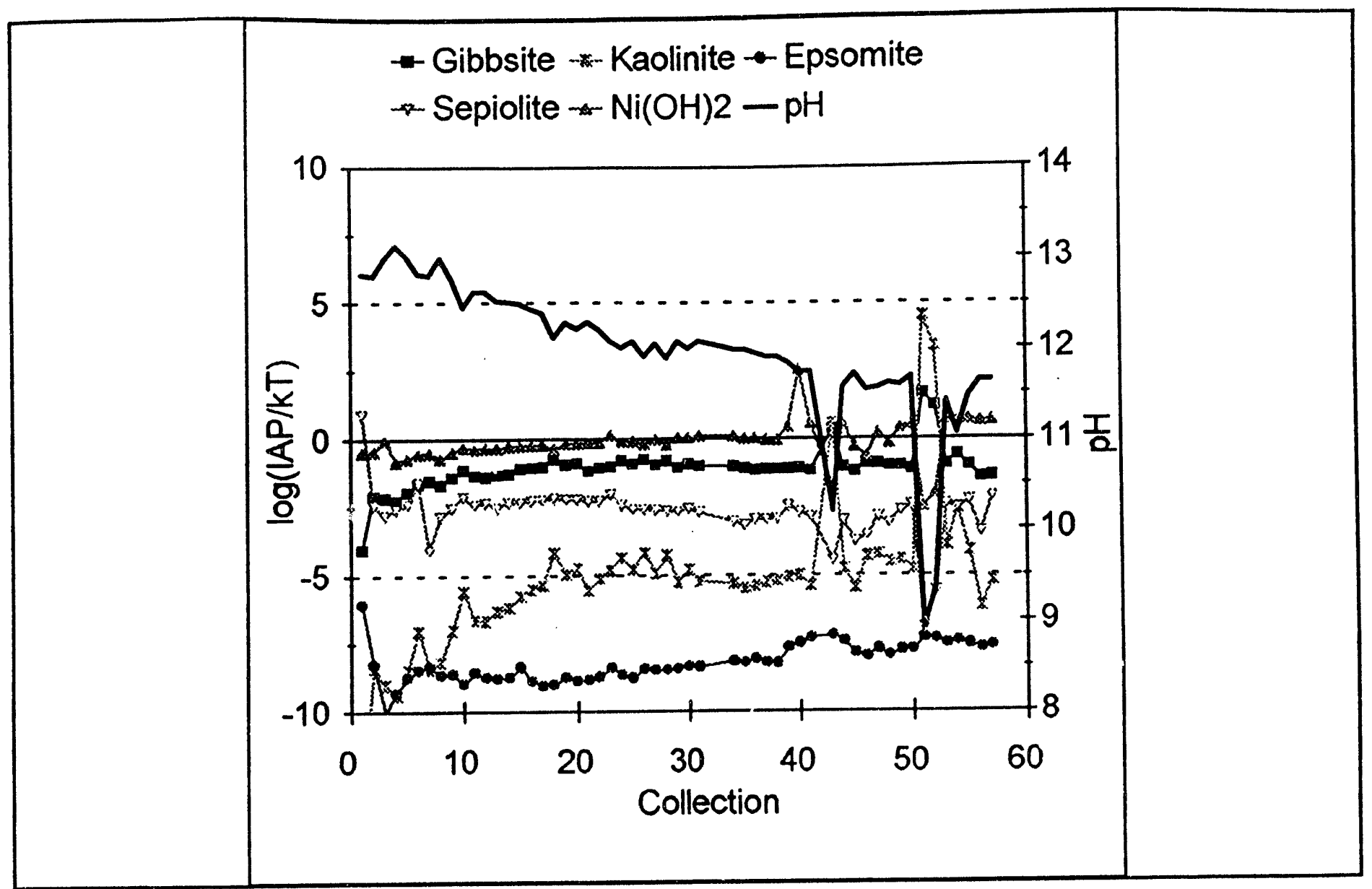

Figure 12.

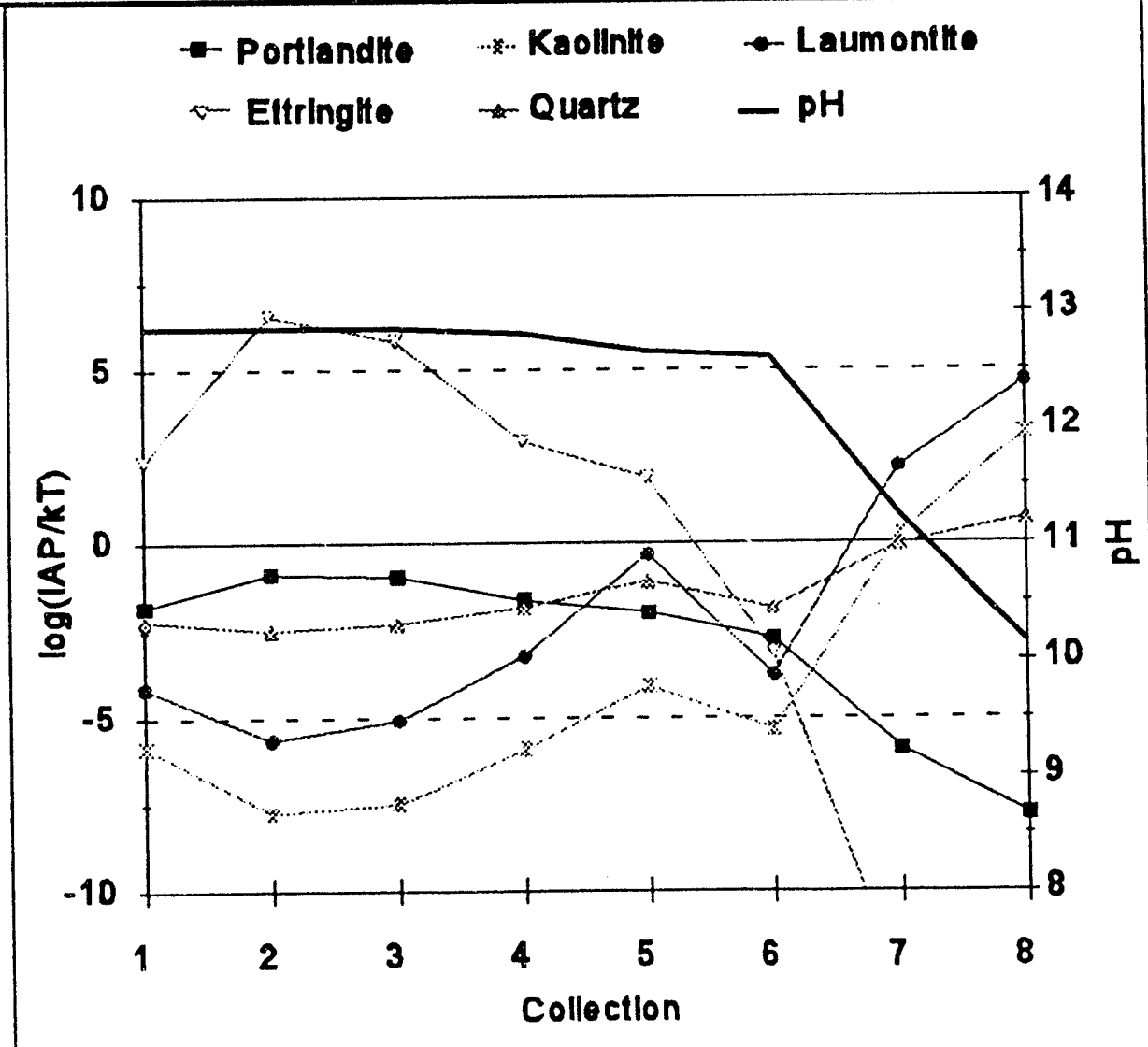

Pilot 1 Wet/Dry +CO2

Figure 13. 


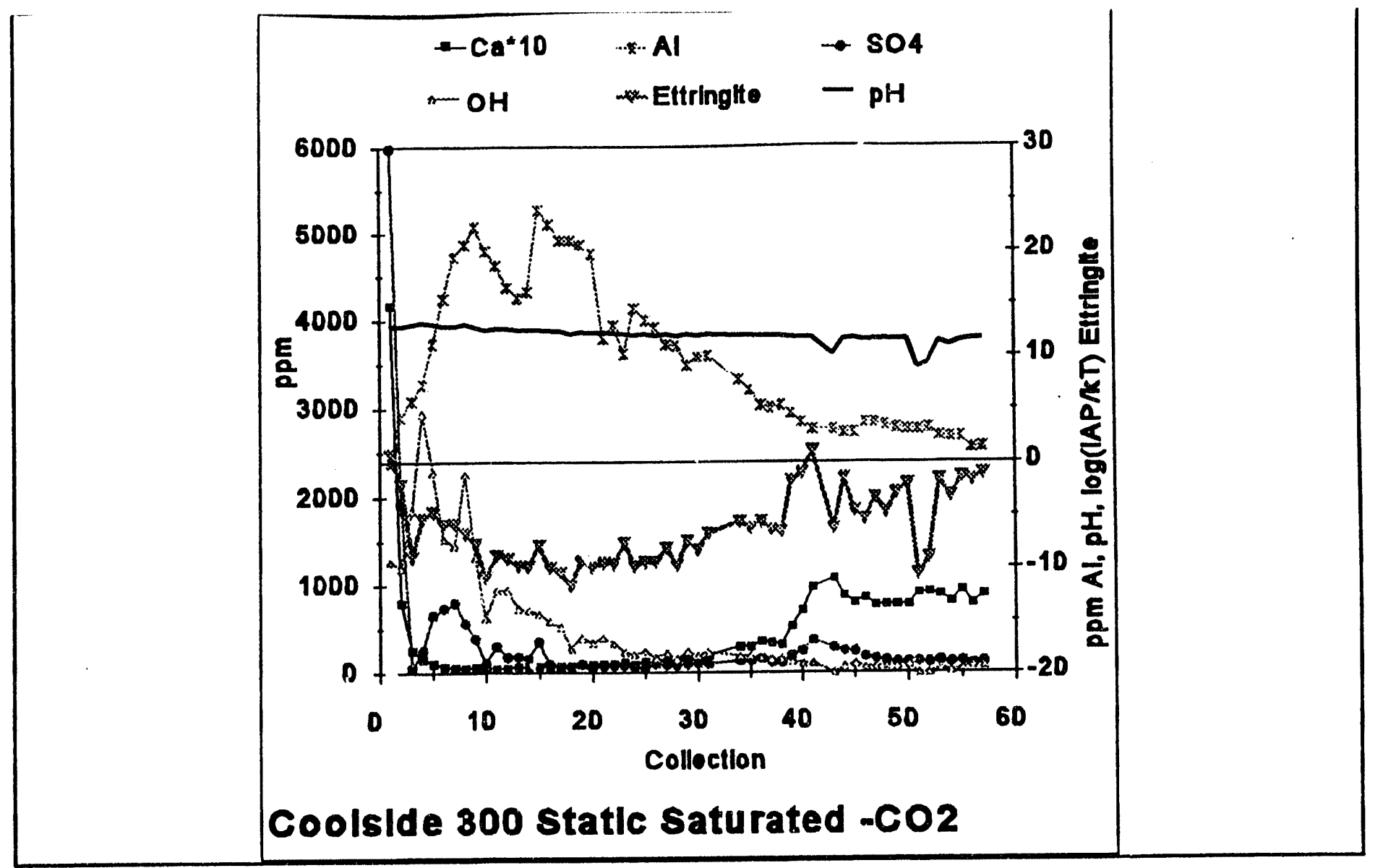

Figure 14. 
leachate.

Cl No major cation interacts significantly with the chloride ion. Minor cations $(\mathrm{Pb}, \mathrm{Zn}$, $\mathrm{Fe}$ and $\mathrm{Mn}$ ) may form minor amounts of hydroxy-chloride minerals as mentioned later. Its major effect is also in contributing to the ionic strength of the leachate.

Al Free Al will be available from the dissolution of alumina $\left(\mathrm{Al}_{2} \mathrm{O}_{3}\right)$. It is the only trivalent ion which forms a soluble hydroxide. Initially formed is dimorphous boehmite/diaspore ( $\mathrm{AlOOH}$ or $\mathrm{Al}_{2} \mathrm{O}_{3}{ }^{*} \mathrm{H}_{2} \mathrm{O}$ ), the basic oxide of alumina. Diaspore is favored over boehmite by $\sim 0.1 \mathrm{kcal} / \mathrm{mole}$. They hydrate slowly to gibbsite $\left(\mathrm{Al}(\mathrm{OH})_{3}\right.$ or $\mathrm{Al}_{2} \mathrm{O}_{3}{ }^{*} 3 \mathrm{H}_{2} \mathrm{O}$ ) at room temperature. Gibbsite is also artificially formed by passing $\mathrm{CO}_{2}$ into alkali aluminate solution, which describes Coolside leachate conditions. Kaolinite $\left(\mathrm{Al}_{2} \mathrm{Si}_{2} \mathrm{O}_{5}(\mathrm{OH})_{4}\right)$, which WATEQ indicates approaches or passes saturation at lower $\mathrm{pH}$ levels, also dissolves to or forms from gibbsite and silicic acid. Diaspore, gibbsite and kaolinite have been chosen as minerals of interest. Other aluminosilicates are mentioned below. These minerals, for the most part, are not expected to form from solution or control the solution chemistry; however their inclusion does reflect the solute availability of the component ions which in some cases is of interest.

Micas Micas have never been shown to control water chemistry. Reversibility has not been shown, so there is no reason to believe that they attain equilibrium solubilities. $K$ mica $\left(\mathrm{KAl}_{2}\left(\mathrm{Si}_{3} \mathrm{Al}\right) \mathrm{O}_{10}(\mathrm{OH})_{2}\right)$ shows a sometimes extreme supersaturation at lower leachate $\mathrm{pH}$ and appears to be driven by the leachate chemistry.

Feldspars WATEQ indicates that the feldspars anorthite $\left(\mathrm{CaAl}_{2} \mathrm{Si}_{2} \mathrm{O}_{8}\right)$, albite $\left(\mathrm{NaAlSiSi}_{2} \mathrm{O}_{8}\right)$ and adularia $\left(\mathrm{KAISiSi}{ }_{2} \mathrm{O}_{8}\right)$, become supersaturated. These minerals form a substitutional solid solution. The degree of saturation is adularia $>$ albite $>$ anorthite. They appear also to be driven by leachate chemistry. As adularia appears to be one of the few possible mineral forms containing $\mathrm{K}$, and albite, likewise, contains $\mathrm{Na}$, these two will be retained. Authogenic feldspars are know to form in nature, but are not 
considered to be an important species here.

Pyroxenes Clinoenstatite $\left(\mathrm{Mg}_{2} \mathrm{Si}_{2} \mathrm{O}_{6}\right.$ or $\mathrm{MgSiO}_{3}$ ), analcime $\left(\mathrm{NaAlSi}_{2} \mathrm{O}_{6}{ }^{*} \mathrm{H}_{2} \mathrm{O}\right.$ ) (hydrated Jadeite) and diopside $\left(\mathrm{CaMgSi}_{2} \mathrm{O}_{6}\right)$ exhibit supersaturation. Diopside, at times, appears to be driven by pH mediated silica availability, and independent of or opposite $\mathrm{pH}$ at other times. Its often very high degree of supersaturation argues against its importance in leachate chemistry, but its role, if any, remains to be determined. Clinoenstatite will be retained, as it is the major magnesium silicate. Analcime rarely approaches saturation, appears to be driven by leachate chemistry and would only be present in minor amounts, if any, so will not be retained.

SO, Sulfate availability is controlled by the equilibrium dissolution of anhydrite $\left(\mathrm{CaSO}_{4}\right)$ and gypsum $\left(\mathrm{CaSO}_{4}{ }^{2} \mathrm{H}_{2} \mathrm{O}\right)$. Anhydrite crystals are not common. Anhydrite converts slowly to gypsum with a corresponding increase in volume giving long-term swell. It is also slightly more soluble than gypsum. WATEQ indicates that both are uniformly at, or slightly under, saturation, with anhydrite slightly less saturated, as expected. Gypsum will be retained as a mineral which controls leachate chemistry. Another source of sulfate is the dissolution of epsomite $\left(\mathrm{MgSO}_{4}{ }^{*} 7 \mathrm{H}_{2} \mathrm{O}\right)$. It is extremely soluble and is expected to contribute to the very high initial sulfate concentration in the leachate, lut is not expected to be present or to control chemistry except initially. Ettringite $\left(\mathrm{Ca}_{6} \mathrm{Al}_{2}\left(\mathrm{SO}_{4}\right)_{3}(\mathrm{OH})_{12}{ }^{2} 26 \mathrm{H}_{2} \mathrm{O}\right)$ is commonly found in $\mathrm{CaO}-\mathrm{Al}_{2} \mathrm{O}_{3}-\mathrm{CaSO}_{4}-\mathrm{H}_{2} \mathrm{O}$ systems on mineral surfaces and in pore spaces. It is partly decomposed by water to an alkali. WATEQ indicates that, in most cases, ettringite is only initially supersaturated and drops well below saturation very quickly (e.g., Figure 13). It will be retained because of its inplication in swell. Other sulfate minerals are mentioned below.

$\mathrm{Ca}$ and $\mathrm{Mg}$, Carbonates and Hydroxides The interactions between these drive much of the leachate chemistry: Ca because of its abundance, $\mathrm{Mg}$ because of its interchangability with $\mathrm{Ca}$, and carbonates and hydroxides because of their implication 
in $\mathrm{pH}$ control. Possible major mineral forms which WATEQ indicates are often or always supersaturated are calcite $\left(\mathrm{CaCO}_{3}\right)$, aragonite $\left(\mathrm{CaCO}_{3}\right)$, brucite $\left(\mathrm{Mg}(\mathrm{OH})_{2}\right)$, dolomite $\left(\mathrm{Ca} M \mathrm{Mg}\left(\mathrm{CO}_{3}\right)_{2}\right)$, hydromagnesite $\left(\mathrm{Mg}_{5}\left(\mathrm{CO}_{3}\right)_{4}(\mathrm{OH})_{2}{ }^{*} 4 \mathrm{H}_{2} \mathrm{O}\right)$, magnesite $\left(\mathrm{MgCO}_{3}\right)$, dimorphic $\mathrm{MgCO}_{3}$, and huntite $\left(\mathrm{Mg}_{3} \mathrm{Ca}\left(\mathrm{CO}_{3}\right)_{4}\right)$. Periclase $(\mathrm{MgO})$ hydrates to brucite, which may further alter to magnesite and hydromagnestite. A precipitate of the hydrate nesquehonite $\left(\mathrm{MgCO}_{3}{ }^{*} 3 \mathrm{H}_{2} \mathrm{O}\right)$, whose slight solubility is enhanced by the presence of $\mathrm{CO}_{2}, \mathrm{NaCl}$, and $\mathrm{Na}_{2} \mathrm{SO}_{4}$, may aiso be formed at STP. To determine which forms are likely at leachate conditions, an equilibrium diagram which uses log[(activity Ca)/(activity $\mathrm{Mg})]$ vs $\log \left(\mathrm{pCO}_{2}\right)$ to predict equlibrium conditions was plotted over the leachate collection periods. It was found that calcite is favored, with brief movements into brucite, aragonite or dolomitic regimes. For fly ashes, with a lower $\mathrm{Ca} / \mathrm{Mg}$ ratio, most of the collection period remains in the dolomitic regime. Representative equilibrium diagrams are given in Figures 5 and 6 . Calcite has been selected over aragonite, as calcite is the preferred dimorphic form. The conditions under which dolomite is precipitated in nature are not well understood, and attempts to precipitate dolomite from oversaturation have failed. Dolomite is an ordered crystal which prevents its formation from solutions undergoing rapid crystallization. It is possible, however, that dolomite might be formed under conditions of oversaturation and high ionic strength found in Coolside leachate over a long period of time. Dolomite was most likely present in the original sorce of lime for the Coolside tests and is of interest. An additional magnesium carbonate of possible interest is artinite $\left(\mathrm{Mg}_{2} \mathrm{CO}_{3}(\mathrm{OH})_{2}{ }^{\star}{ }^{3} \mathrm{H}_{2} \mathrm{O}\right)$, which exhibits supersaturation but appears to be driven by leachate chemistry. It will also be retained.

Ca and $\mathrm{Mg}$ Silicates Forsterite $\left(\mathrm{Mg}_{2} \mathrm{SiO}_{4}\right)$, sepiolite $\left(\mathrm{Mg}_{4} \mathrm{Si}_{6} \mathrm{O}_{15}(\mathrm{OH})_{2}{ }^{*} 6 \mathrm{H}_{2} \mathrm{O}\right)$ and talc $\left(\mathrm{Mg}_{3} \mathrm{Si}_{4} \mathrm{O}_{10}(\mathrm{OH})_{2}\right)$ are indicated to be supersaturated. Talc tends to form in high ionic strength brines at low temperature, but sepiolite tends to precipitate preferentially. Sepiolite should continue to be considered, as its precipitation also lowers $\mathrm{pH}$. Two other calcium-aluminum silicates, prehnite $\left(\mathrm{Ca}_{2} \mathrm{Al}_{2} \mathrm{Si}_{3} \mathrm{O}_{10}(\mathrm{OH})_{2}\right)$ and laumontite $\left(\mathrm{CaAl}_{2} \mathrm{Si}_{4} \mathrm{O}_{12}{ }^{*} 4 \mathrm{H}_{2} \mathrm{O}\right)$, show supersaturation but their significance, if any, is currently 
unknown. Prehnite does not seem to be driven by leachate $\mathrm{pH}$, while laumontite does. They will continue to be considered.

Minor Species Carriers Mineral carriers of minor ions have little effect on leachate chemistry but will be followed to predict which might be dominant at points in the leachate cycle because the ions are of general interest. It is doubtful that many of these could be confirmed by XRD, as the amounts would be very small. In general, the oxide, hydroxide, carbonate and silicate forms are indicated at appropriate times in the collection cycle.

Ba Barite $\left(\mathrm{BaSO}_{4}\right)$ is relatively insoluble and becomes more so in a salt solution. WATEQ indicates that it is often supersaturated. Witherite $\left(\mathrm{BaCO}_{3}\right)$ is indicated to be supersaturated, but less often.

PO, Ca-hydroxylapatite $\left(\mathrm{Ca}_{5}\left(\mathrm{PO}_{4}\right)_{3} \mathrm{OH}\right)$ is the major phosphate carrier. WATEQ indicates a fairly significant degree of supersaturation. The fluor-apatite would be preferred in the presence of fluorine. It forms a solid solution with $\mathrm{Ca}>\mathrm{Pb}>\mathrm{Na}>\mathrm{K}$.

Pb Litharge/massicot ( $\mathrm{PbO}$ dimorphs) probably form minor amounts of $\mathrm{Pb}(\mathrm{OH})_{2}$. Other $\mathrm{Pb}$ minerals possibly formed include cerrusite $\left(\mathrm{PbCO}_{3}\right)$, anglesite $\left(\mathrm{PbSO}_{4}\right)$, larnakite $\left(\mathrm{Pb}_{2}\left(\mathrm{SO}_{4}\right) \mathrm{O}\right)$, and laurionite $(\mathrm{Pb}(\mathrm{OH}) \mathrm{Cl})$, one of the very few $\mathrm{Cl}$ minerals. WATEQ indicates supersaturation for each of these at various times. $\mathrm{Pb}$ compounds, however, are not known for solubility.

$\mathrm{Cu}$ Tenorite $(\mathrm{CuO})$, malachite $\left(\mathrm{Cu}_{2}\left(\mathrm{CO}_{3}\right)(\mathrm{OH})_{2}\right)\left(\mathrm{crystals}\right.$ rare, but slightly water- $\mathrm{CO}_{2}$ soluble), atacamite $\left(\mathrm{Cu}_{2}(\mathrm{OH})_{3} \mathrm{Cl}\right)$ (another of the few $\mathrm{Cl}$ minerals; alters to malachite; formed by oxidation of other Cu minerals, especially in arid saline environments), and tsumebite $\left(\mathrm{CuPb}_{2}\left(\mathrm{PO}_{4}\right)\left(\mathrm{SO}_{4}\right)(\mathrm{OH})\right)($ unlikely to be found) have supersaturation indicated by WATEQ. 
Cd Monteponite ( $\mathrm{CdO}), \mathrm{Cd}(\mathrm{OH})_{2}, \mathrm{Cd}(\mathrm{OH}) \mathrm{Cl}, \mathrm{CdSiO}_{3}$ and otavite $\left(\mathrm{CdCO}_{3}\right)$ exhibit varying degrees of supersaturation. Dtavite is supersaturated only in the fly ash system. In the Coolside leaching, the higher $\mathrm{Ca} / \mathrm{Mg}$ ratio leads to preferential calcite formation.

Zn Zincite $(\mathrm{ZnO}), \mathrm{Zn}(\mathrm{OH})_{2}, \mathrm{Zn}_{2}(\mathrm{OH})_{3} \mathrm{Cl}, \mathrm{ZnCO}_{3}{ }^{*} \mathrm{H}_{2} \mathrm{O}$ and $\mathrm{ZnSiO}{ }_{3}$ are indicated.

Mn Pyrocroite $\left(\mathrm{Mn}(\mathrm{OH})_{2}\right)$ and rhodochrisite $\left(\mathrm{MnCO}_{3}\right)$ exhibit varying degrees of supersaturation. The oxide form, pyrolusite, remains well undersaturated.

$\mathrm{Ni}$ Bunsenite (NiO), $\mathrm{Ni}(\mathrm{OH})_{2}$ and $\mathrm{Ni}_{2} \mathrm{SiO}_{4}$ are indicated.

Fe There is no analytical information on relative amounts of divalent and trivalent $\mathrm{Fe}$. Goethite $(\mathrm{FeOOH})$, the trivalent analogue to diaspore $(\mathrm{AlOOH})$, does not show saturation. Also, no divalent Fe mineral approaches saturation, so it is probable that hematite/maghemite $\left(\mathrm{Fe}_{2} \mathrm{O}_{3}\right)$ and magnetite $\left(\mathrm{FeFe}_{2} \mathrm{O}_{4}\right)$ are nearly insoluble.

\section{Future Activities}

Refinement of mineral selection will continue. Further investigation is necessary to explain the disparate behavior of different columns. Results must be expanded to include field lysimiters. Thaumasite and mullite will be added to the thermodynamics data base.

An asphalt mix design will be developed using natural aggregates blended with synthetic aggregate produced from FBC. 
Appendix A

Moisture Density Curves for FBC-Modified Soils 
$100 \% \mathrm{FBC}$

STANDARD

OPTIMUM MOISTURE CONTENT $(\%)=27.8$

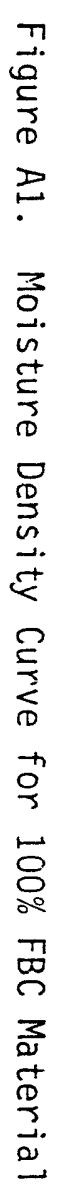
$W L=$
$H P=$
$O E G=3$
OPTIMUM DRY DENSITY $=76.7$ PCF

용

\section{$\dot{0}$}

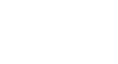

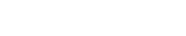

OPTIAUY DRY OENSITY $=70.7$ PCF 
$4 \%$ FBC

STANDARD

OPTIMUM MOISTURE CONTENT $(\%)=23.9$

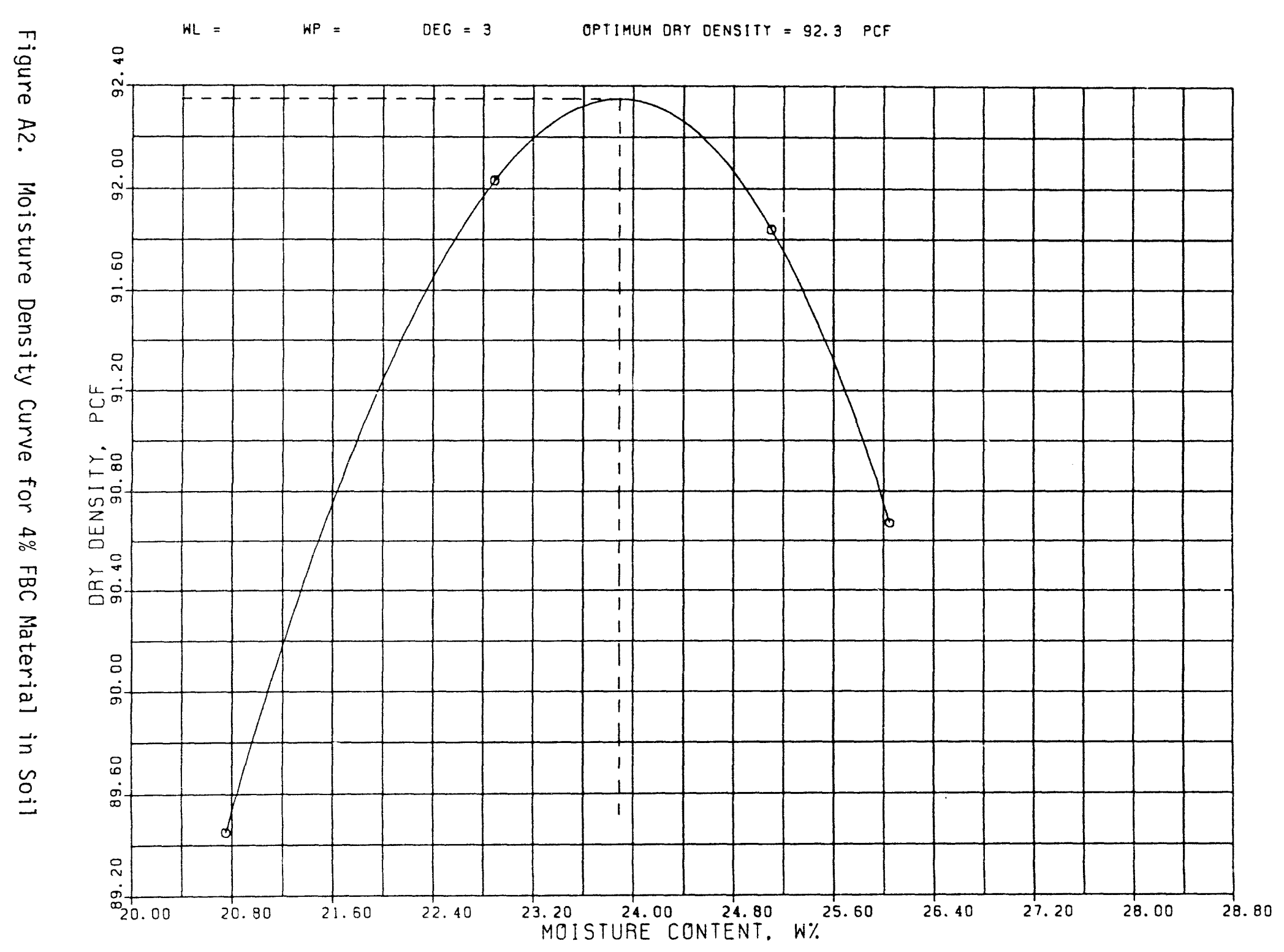




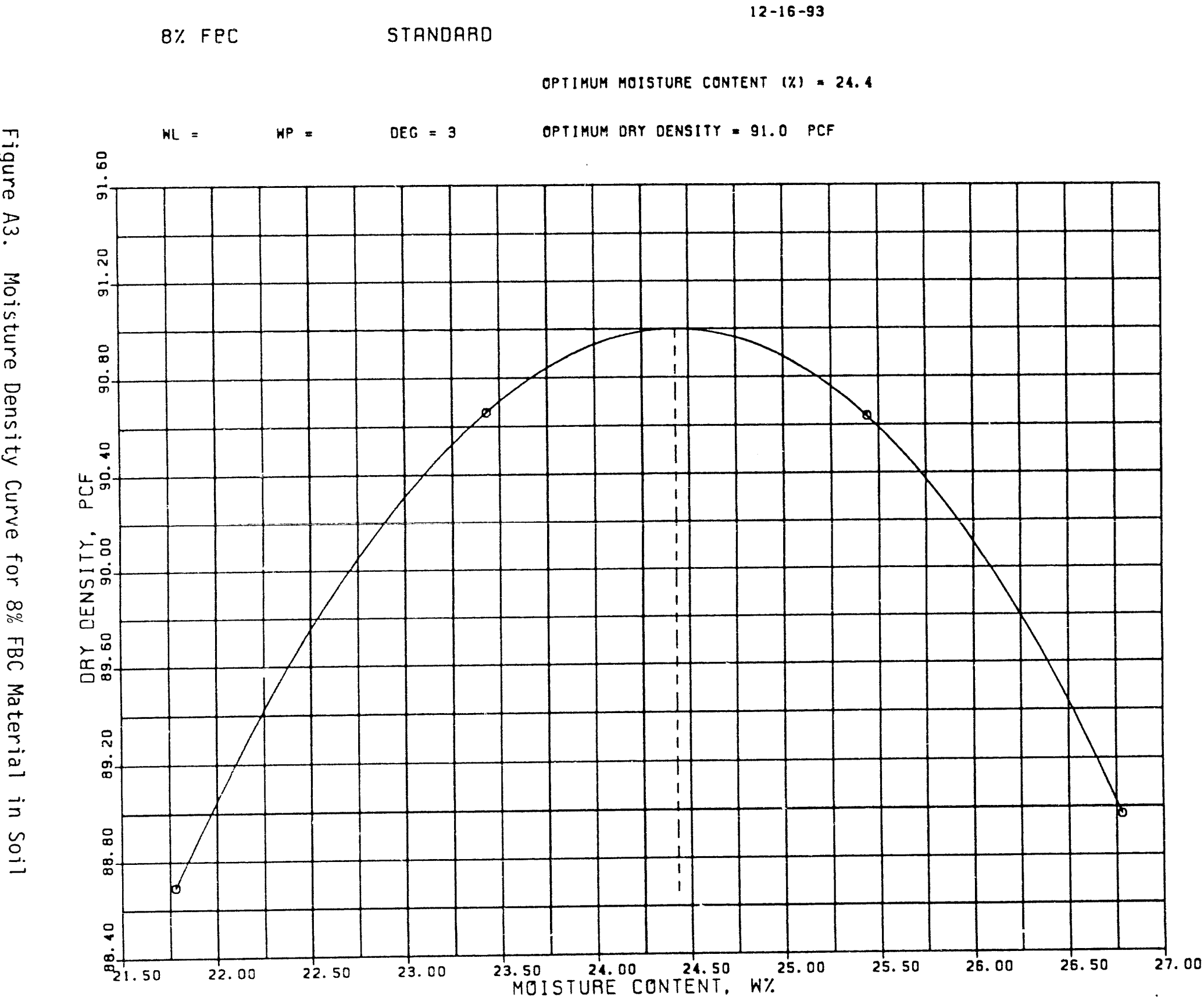


OPTIMUM MOISTURE CONTENT $(\%)=25.1$

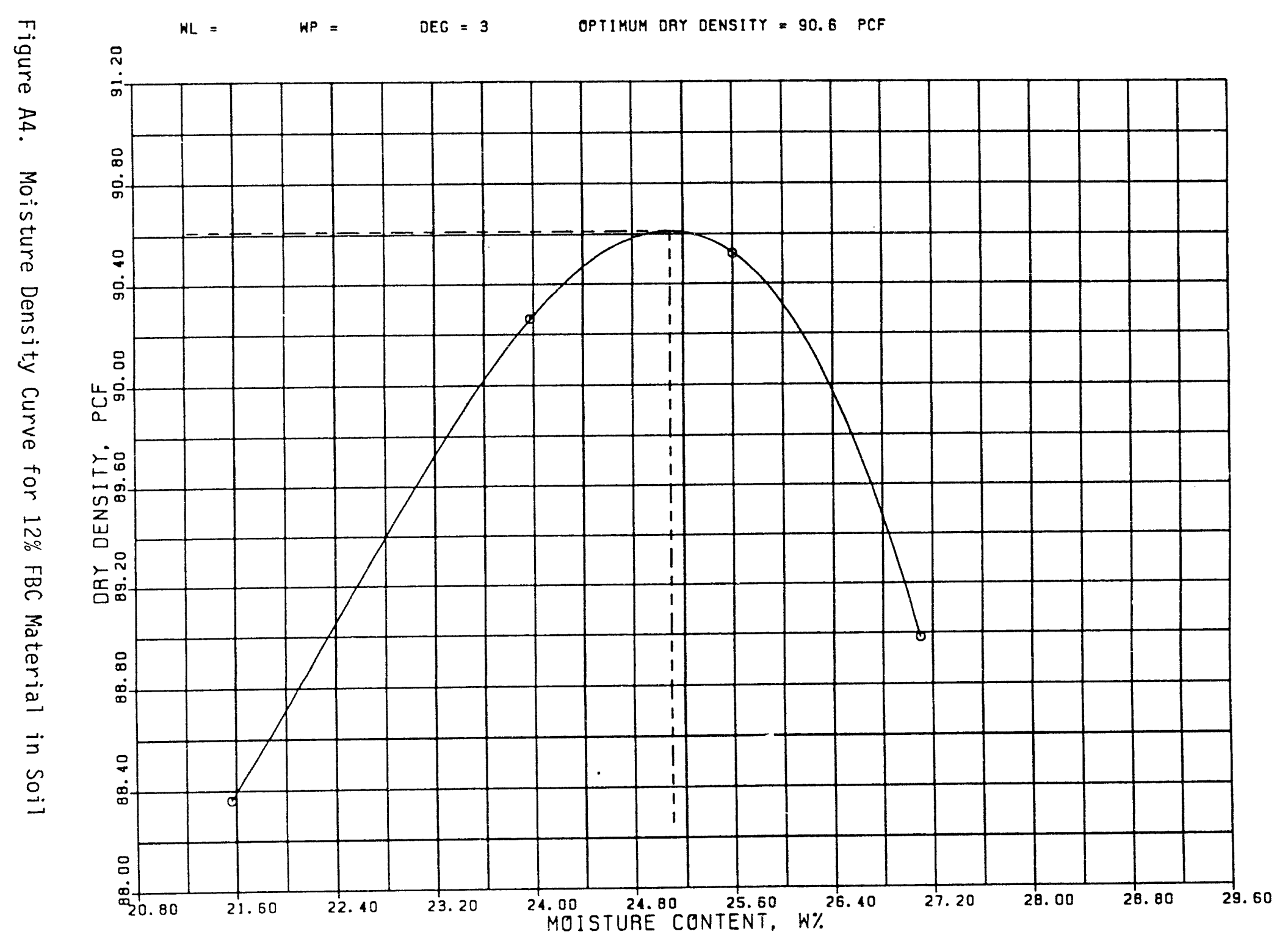


$100 \%$ SOIL

STANDARD

OPTIMUM MOISTURE CONTENT $(\%)=19.4$

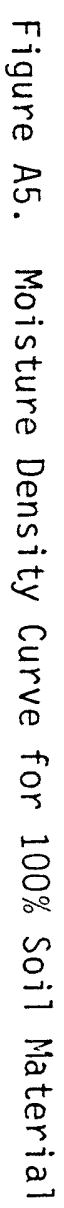

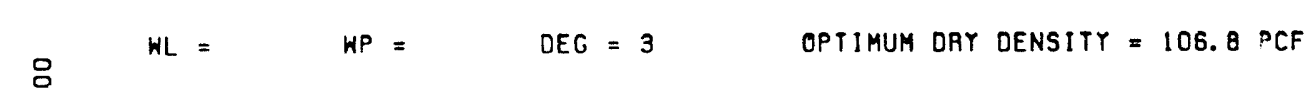

$$
\stackrel{\dot{\Xi}}{\stackrel{9}{-}}
$$

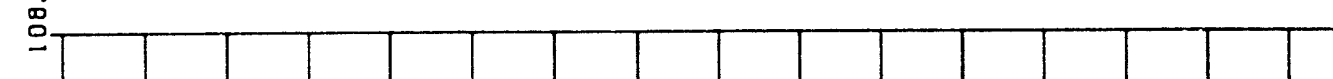

$$
\text { 운 }
$$

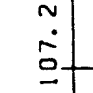$$
\text { 문. }
$$$$
\text { u范宫 }
$$$$
a
$$ 


\section{Coolside Waste Management Research Technical Progress Report \\ Contract No: DE-AC21-91MC28162}

\section{Report Period: February 1, 1994 to February 28, 1994}

\section{Summary of Progress for the Period}

Unusually wet and cold weather resulted in the field lysimeters having to be sampled on a biweekly basis through the reporting period. A review meeting was held on February 11, in Library, at CONSOL R\&D, Inc.

Monitoring for expansion continued. The tests 'iave been conducted for over a year and the materials are still in a primary swell phase. To date the greatest swell has been observed in the unhydrated unaged material with $2.5 \mathrm{lbs}$. of surcharge. The aged unhydrated and the hydrated materials show much less swell. The details of the monitoring are discussed herein.

\section{Phase I, Task 2, Swell Tests}

Monitoring of swell continued on the hydrated (Figure 1) and non hydrated (Figure 2 and 3) FBC ash samples. Both types are still in the primary swell phase after one year of monitoring. All samples were remolded near $95 \%$ of standard maximum dry density and optimum moisture content. The samples were remolded in CBR molds (6" diameter, 4.584" height), and swell was monitored under the following conditions:

approximately $12.5 \mathrm{lb}$. surcharge, no age time approximately $2.5 \mathrm{lb}$. surcharge, no age time approximately $12.5 \mathrm{lb}$. surcharge, 7 days age time approximately $2.5 \mathrm{lb}$. surcharge, 7 days age time

Time of aging represents the amount of time before the samples were placed in water. Aged specimens were sealed at room temperature to prevent moisture loss before placement into the 


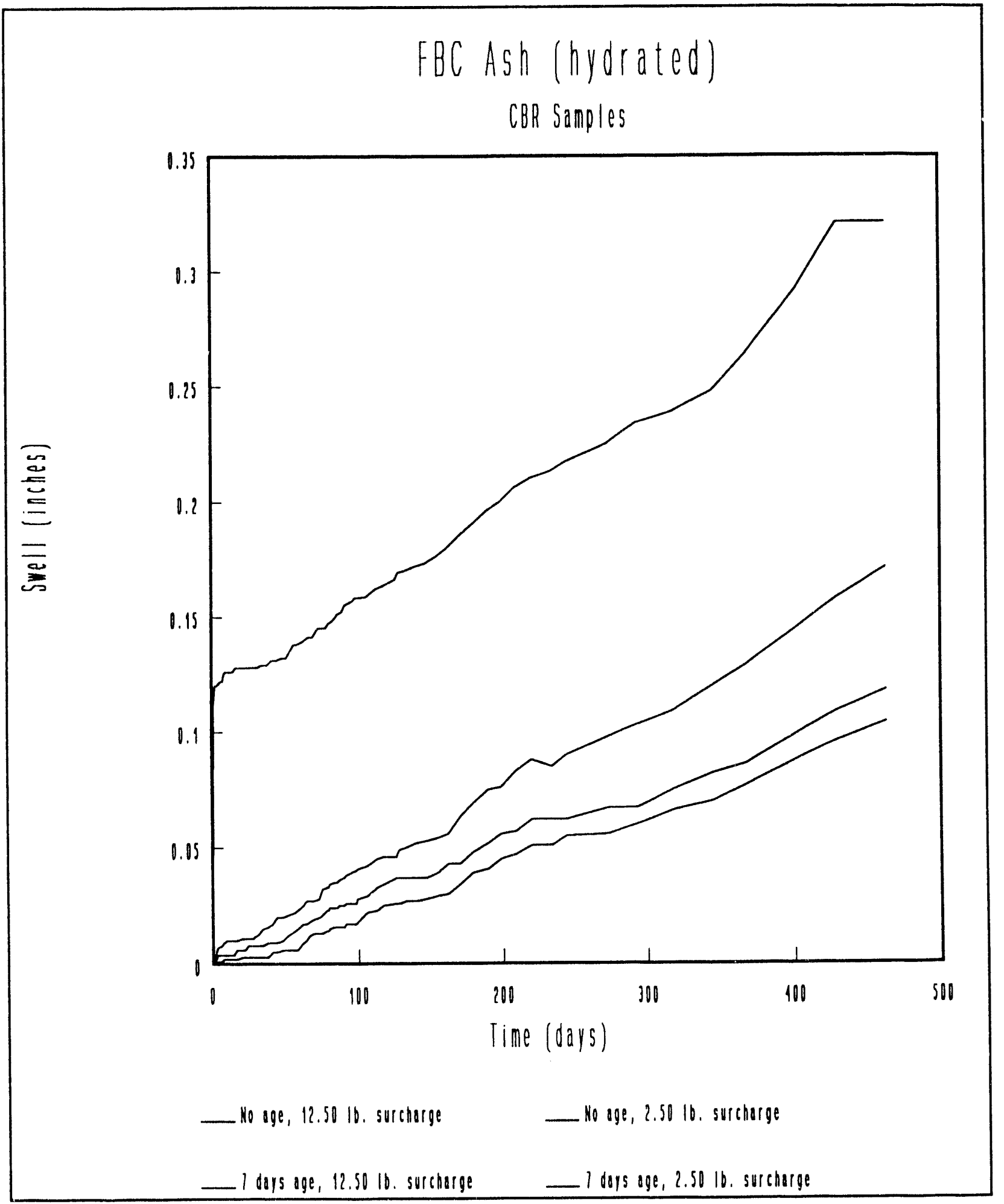

Figure 1. Swell versus Time, Hydrated FBC Ash. 


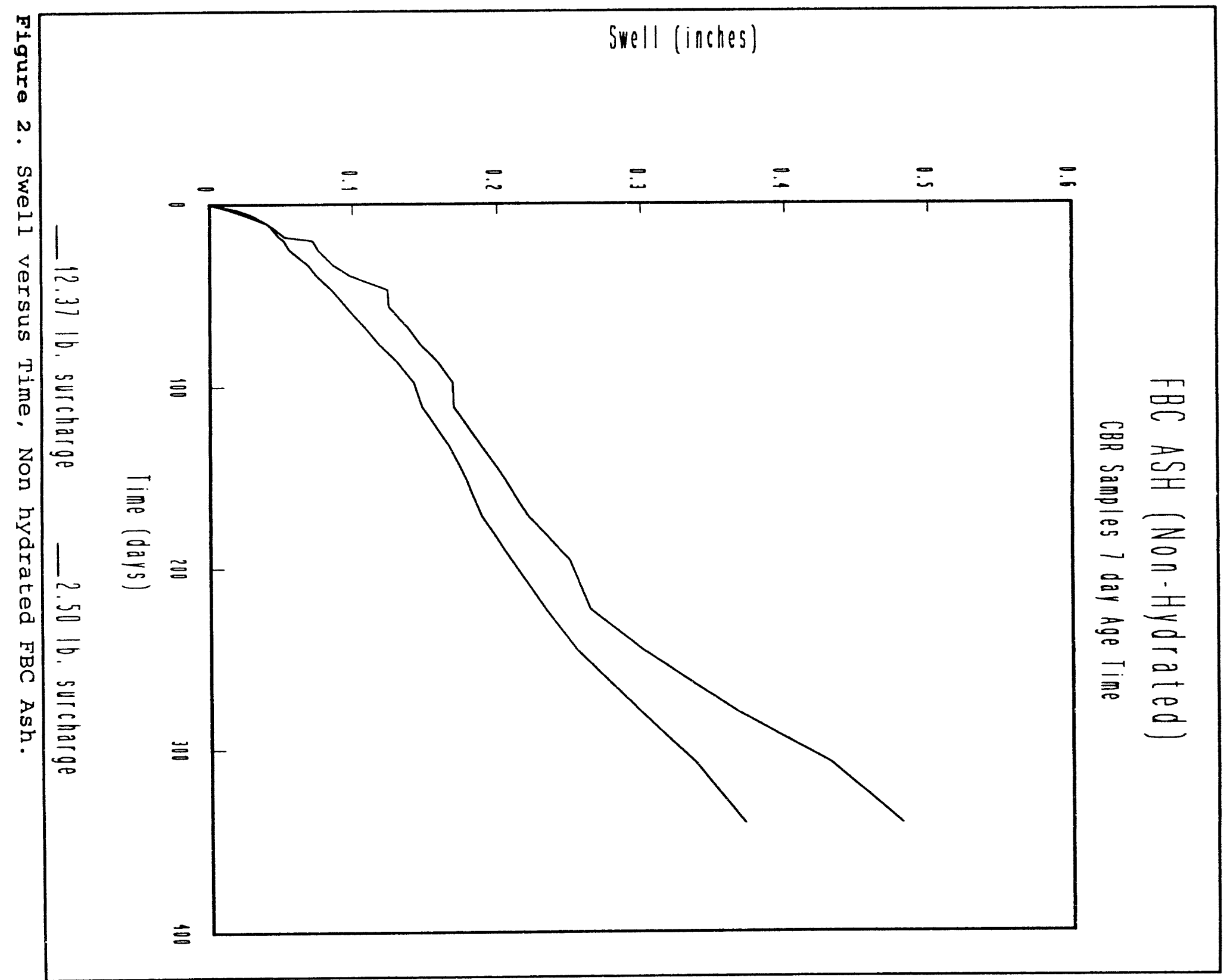




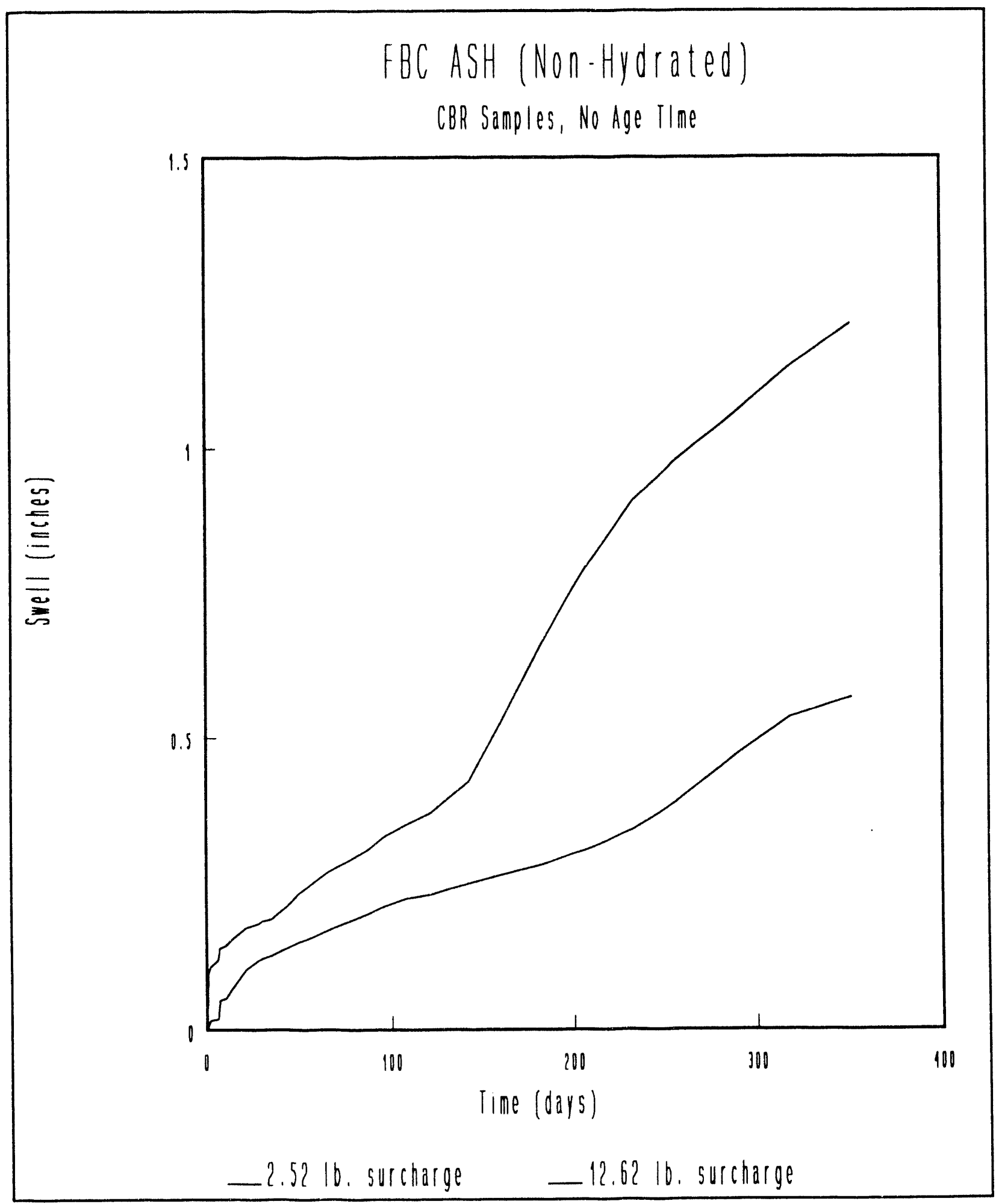

Figure 3. Swell versus Time, Non-hydrated FBC Ash. 
water tank.

Monitoring of swell also continued on two samples of FBC pellets (Figure 4). The pellets were loosely placed in CBR molds. Surcharge weights (approximately 2.5 and 12.5 pounds) were placed on the samples prior to saturating in water. Swell is decreasing in the sample with the 2.5 lb. surcharge and continuing to increase for the sample with the $12.5 \mathrm{lb}$., surcharge.

\section{Work Planned for Next Period}

An asphalt mix design will be developed using synthetic FBC aggregate. CBR and swell tests will be performed on FBC soil mixtures. A compilation of the field data to be reported next month is also planned. 


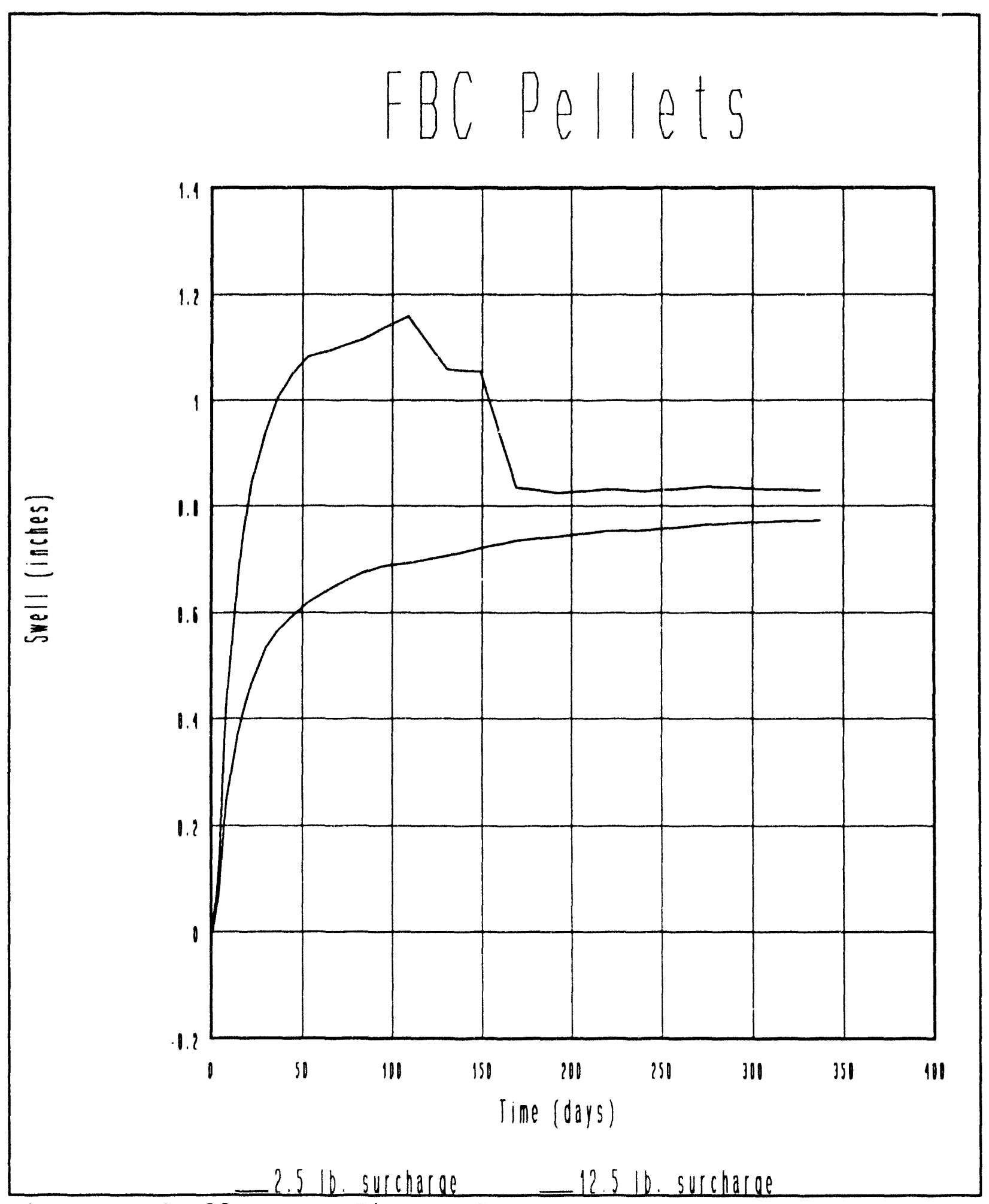

Figure 4. Swell versus Time, FBC Aggregate 


\section{Coolside Waste Management Research \\ Technical Progress Report \\ Contract No: DE-AC21-91MC28162}

\section{Report Period: March 1, 1994 to March 31, 1994}

\section{Summary of Progress for the Period}

Both the coarse and fine aggregate which are to be used in the road demonstration of the FBC pelleis were examined. The proposed materials met the specifications as outlined by the Ohio DOT.

The field lysimeters continued their trend of increasing moisture through the late winter. Many of the elements in the lysimeter leachates show a consistent decline in concentration. For example, $\mathrm{Cl}$ has declined in all the leachates, from levels of tens of thousands of ppm to only a few hundred over a 12 month period. This and other soluble elements, such as sodium, have a release pattern which is constant with simple "washing out" of these elements with time. Other elements such as calcium do not show as simple a pattern. This element is increasing in some leachates and decreasing in others. In addition, an annual pattern of concentration variation is found. This chemistry suggests mineralogical transformations may be exerting a control over the solution chemistry of these materials.

\section{Phase II, Task 1, Subtask 1.3}

\section{Gradation Tests}

Gradation tests were performed on a coarse aggregate (AASHTO No. 8) sample and a fine aggregate (natural sand) sample obtained from a paving contractor in Belmont County, Ohio. The tests were performed to determine if the aggregate met Ohio DOT specification number 404 for aggregates in bituminous concrete surface. The aggregates will be blended with synthetic aggregate, supplied by Consol Inc., produced from FBC ash to make a bituminous concrete surface demonstration project in Belmont County, Ohio. Results of gradation tests show the aggregate meets grain size specifications as seen in Figures 1 and 2. 


\section{Natural Sand}

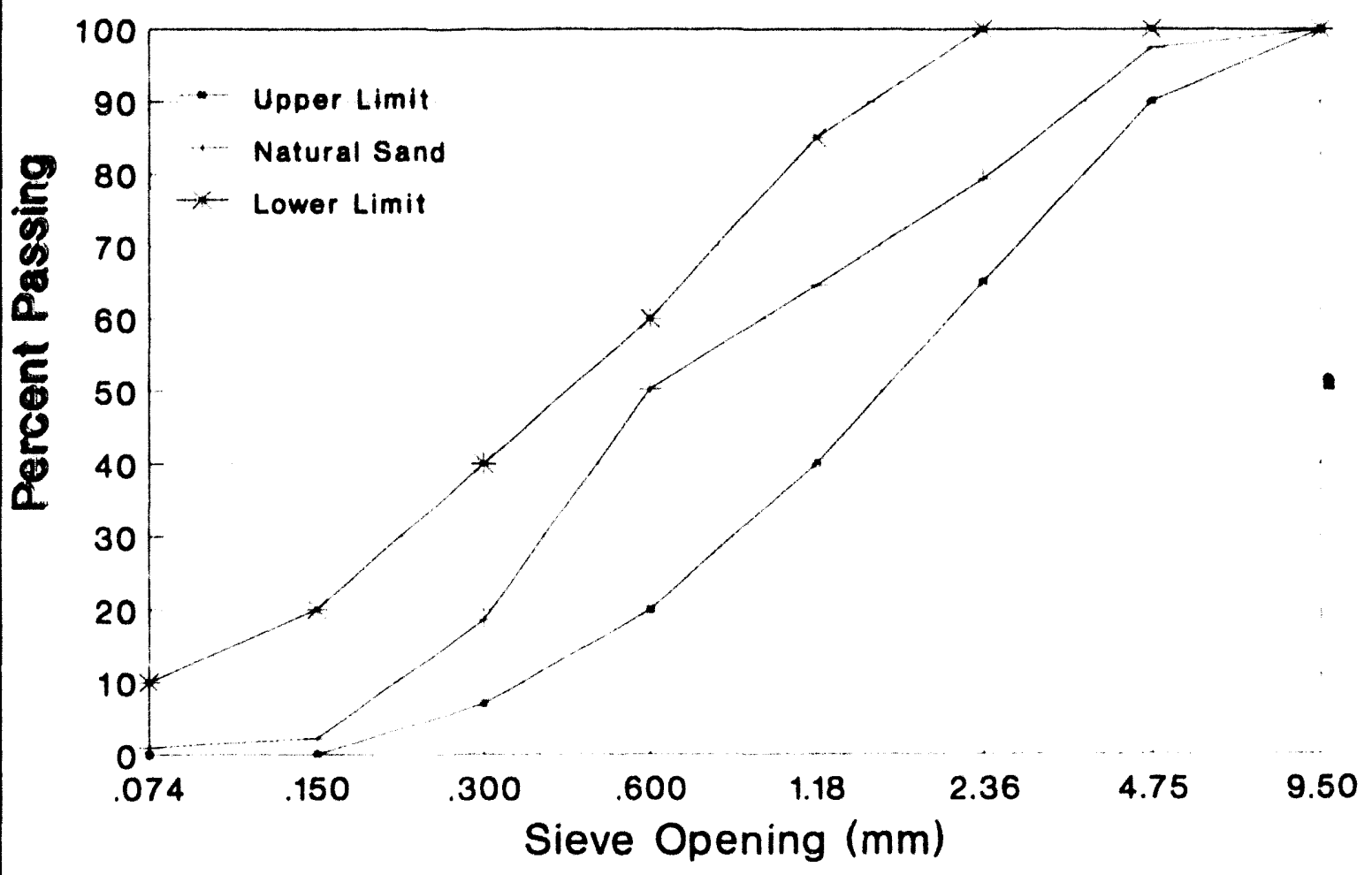

Figure 1. Grain Size of Natural Sand and Specification Limits. 


\section{Phase I, Task 3, Subtask 3.2 Lysimeter Monitoring}

Bed temperatures for each of the lysimeters are plotted in Figure 3. The bed temperatures decreased rapidly over the winter months, to reach a minimum of $5^{\circ} \mathrm{C}$. The temperature minimums attained were identical to those measured over the $92 / 93$ winter months.

The plots of lysimeter moisture levels are shown in Figure 4. Whilst leachate flow rates were significantly higher than for the same period the previous year, overall moisture levels continued to increase within the beds. This indicates that the material within the lysimeters has increased its moisture retention capacity, most likely as a result of a mineralogical transformation creating a material capable of a higher level of hydration. The $\mathrm{pH}$ of the leachates do not show a clear trend among the cells as the $\mathrm{pH}$ in Lysimeter 1 continues to increase, while 3 and 2 remain relatively stable.

Figure 5 shows the change in leachate $\mathrm{pH}$ over time for each of the lysimeters. The graphs show the data measured for port \#3 in each lysimeter (i.e. the left side port on the lowest level). Data from ports 2 and 4 showed similar trends. The measured $\mathrm{pH}$ values from cells 1 and 2 have risen by more than 2 units over the previous 3 months, whilst the values measured in cells 3 and 4 have stayed constant. At this time no explanation is offered for the sudden increase in $\mathrm{pH}$; however, core samples were recently taken from cell 1 and it is hoped that $\mathrm{x}$-ray analysis may provide sufficient data to elucidate the mineralogic transformations which have taken place

Figure 6 plots alkalinity against time for each of the cells. With the exception of cell 2 , alkalinity has continued to decrease with time as the soluble hydroxides have been leached from the beds. The measured alkalinity values for cell 2 have shown a significant increase over the previous 2 months and may be a result of increased leachate flow through the bed causing the solubilization of material previously isolated from the leachate stream. 

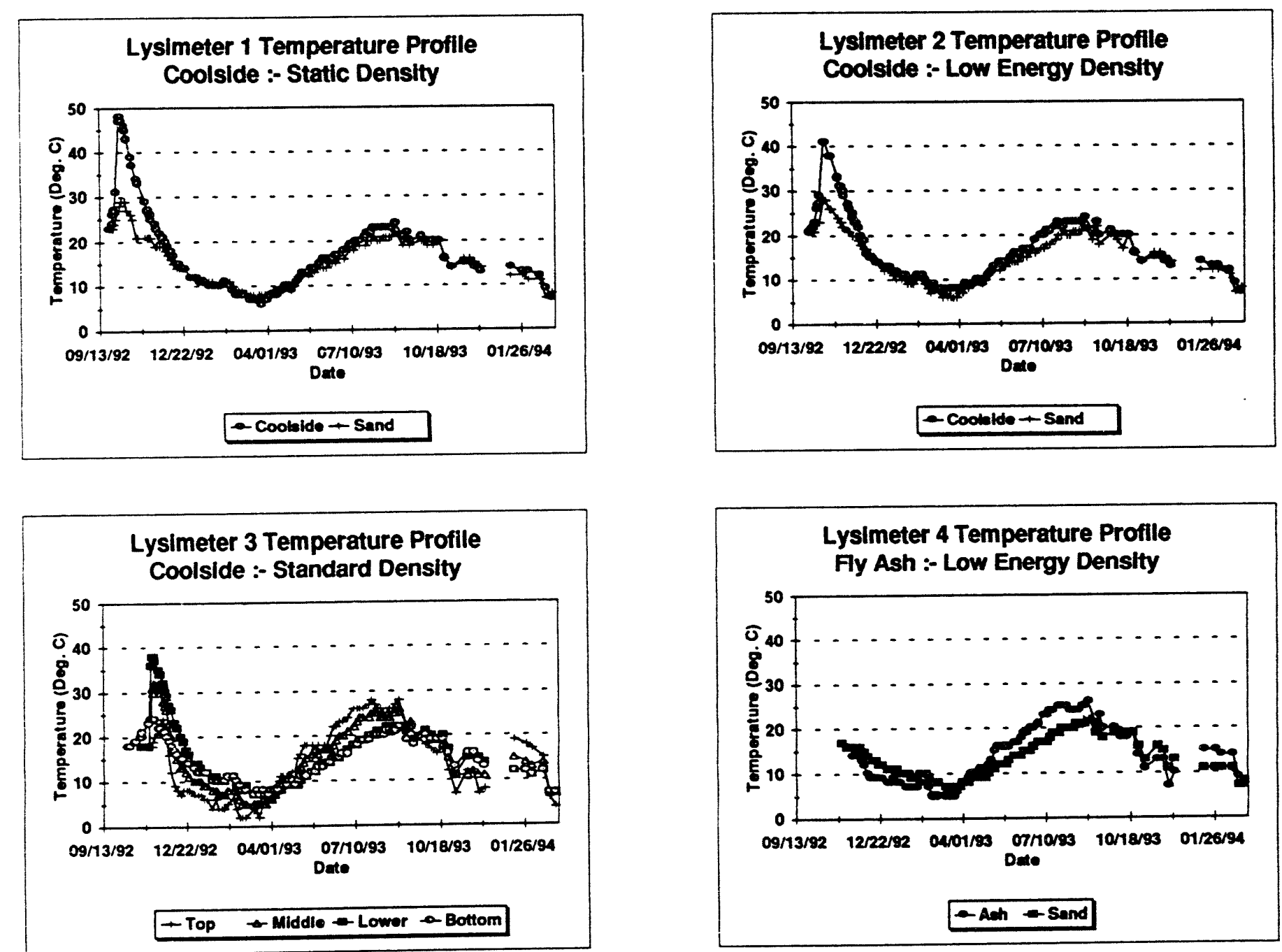

Figure 3 

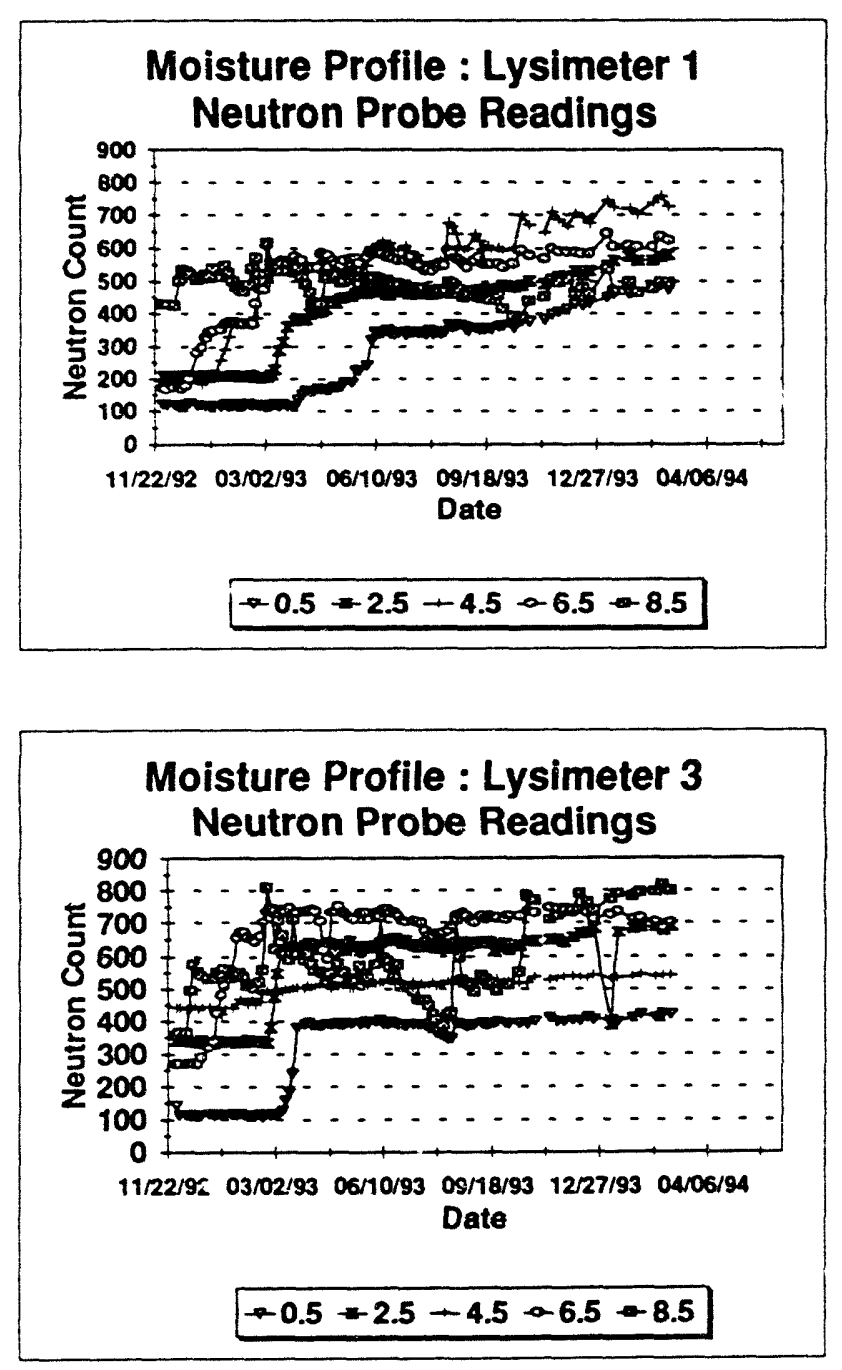
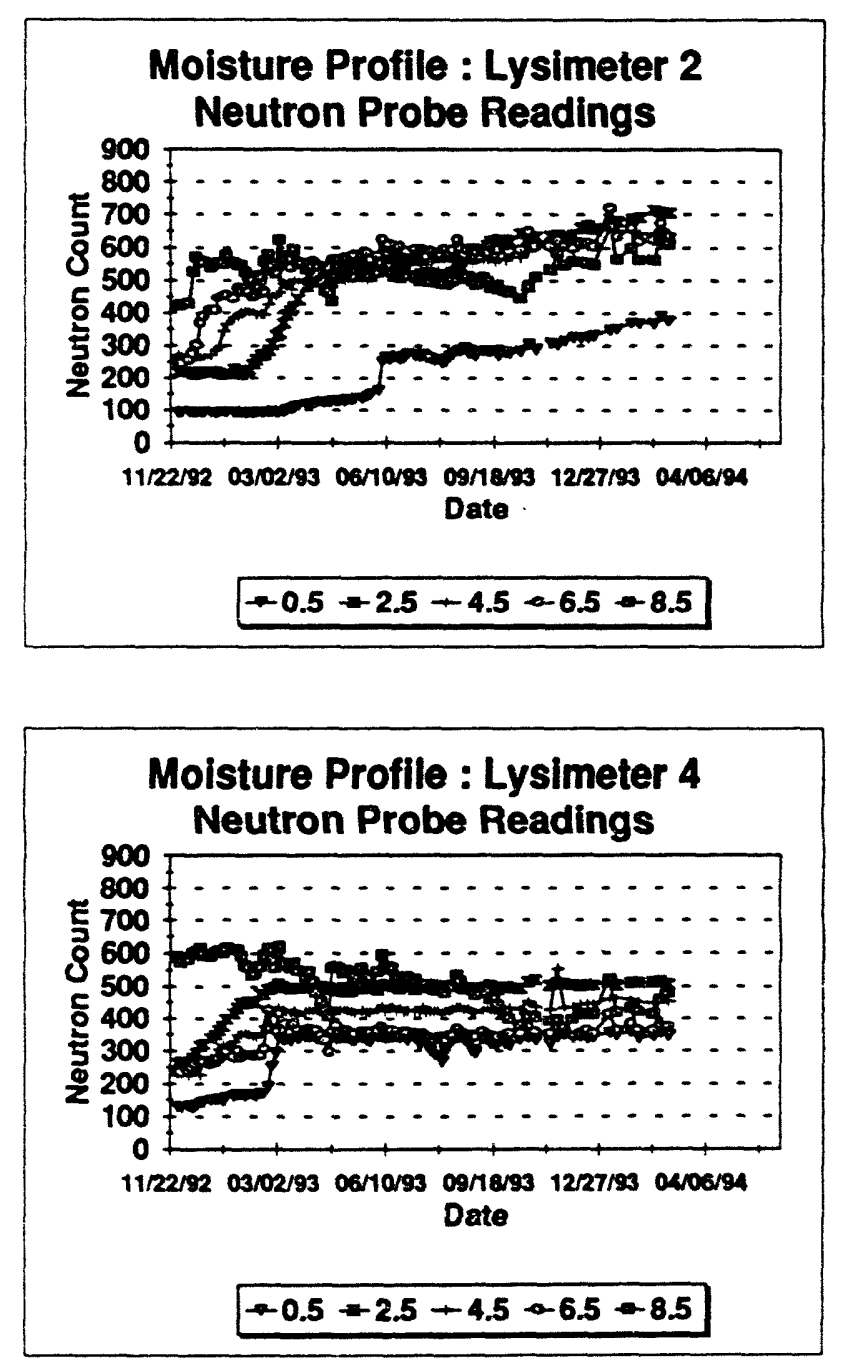

Figure 4 

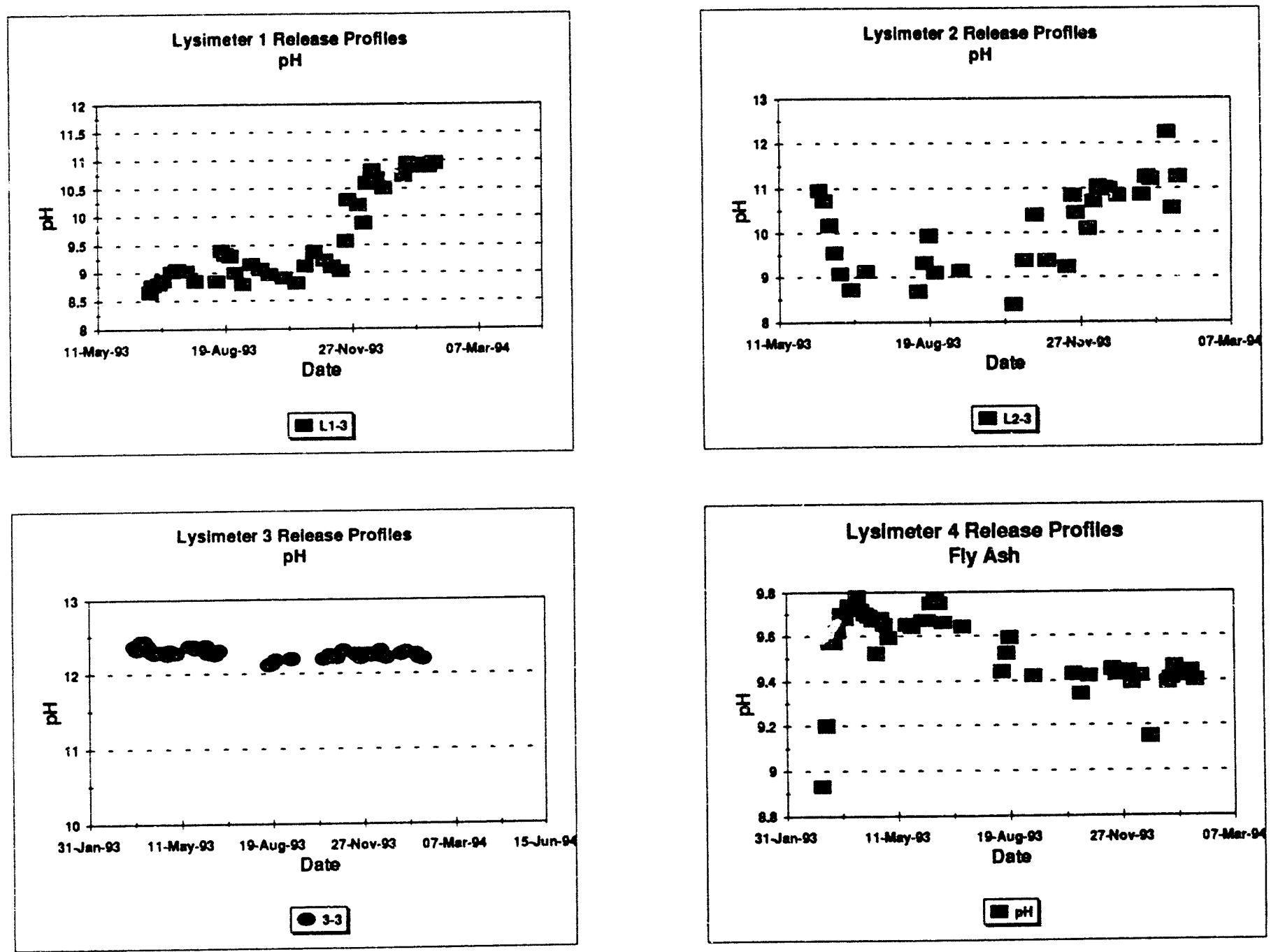

Figure 5 
The plots of conductivity against time for each of the cells (Figure 7) all show a decrease in conductivity, consistent with the removal of soluble species from the bed.

Concentrations of potassium, sodium and calcium are plotted against time in Figures 8, 9 and 10. Sodium and potassium levels have both decreased, with the plots of each metal showing virtually identical trends for each lysimeter, albeit at different concentrations. The calcium plots for cells 1 and 2 also reveal a decrease in concentration over time; however cell 3 shows an increase in leachate calcium concentration with time, possibly indicating the onset of a mineralogic transformation within cell 3 as alkalinity levels have decreased with the removal of stabilizing hydroxide ions from the system.

Chloride and sulphate levels (Figures 11 and 12) have also consistently decreased over the monitoring period. The overall trends of both anions match those of both sodium and potassium very well and also suggest some relationship to calcium levels, albeit to a lesser extent.

The concentration plots of molybdenum and arsenic are shown in Figures 13 and 14. Both plots show an increase in leachate concentration over the late summer months, decreasing again with the onset of winter. High levels of soil $\mathrm{CO}_{2}$ have been observed to result in the mobilization of metals in previous studies. In order to verify this hypothesis, gas monitoring wells have been placed in each lysimeter at depths of 8", 18" and 30" and will be sampled at two week intervals in order to monitor both the build up of $\mathrm{CO}_{2}$ levels within the soil over the summer months and any vertical migration which may occur down into the Coolside material.

\section{Work Planned for Next Period}

An asphalt mix design will be developed using natural aggregates blended with a synthetic aggregate produced from FBC ash. Monitoring of the Montgomery County field site has continued over the period covered by this report. Leachate flow has been observed to be significantly higher than that for the same period in $92 / 93$. As a result, site visits have been conducted two times a week in order to prevent leachate loss from the overflow of the collecting vessels. 

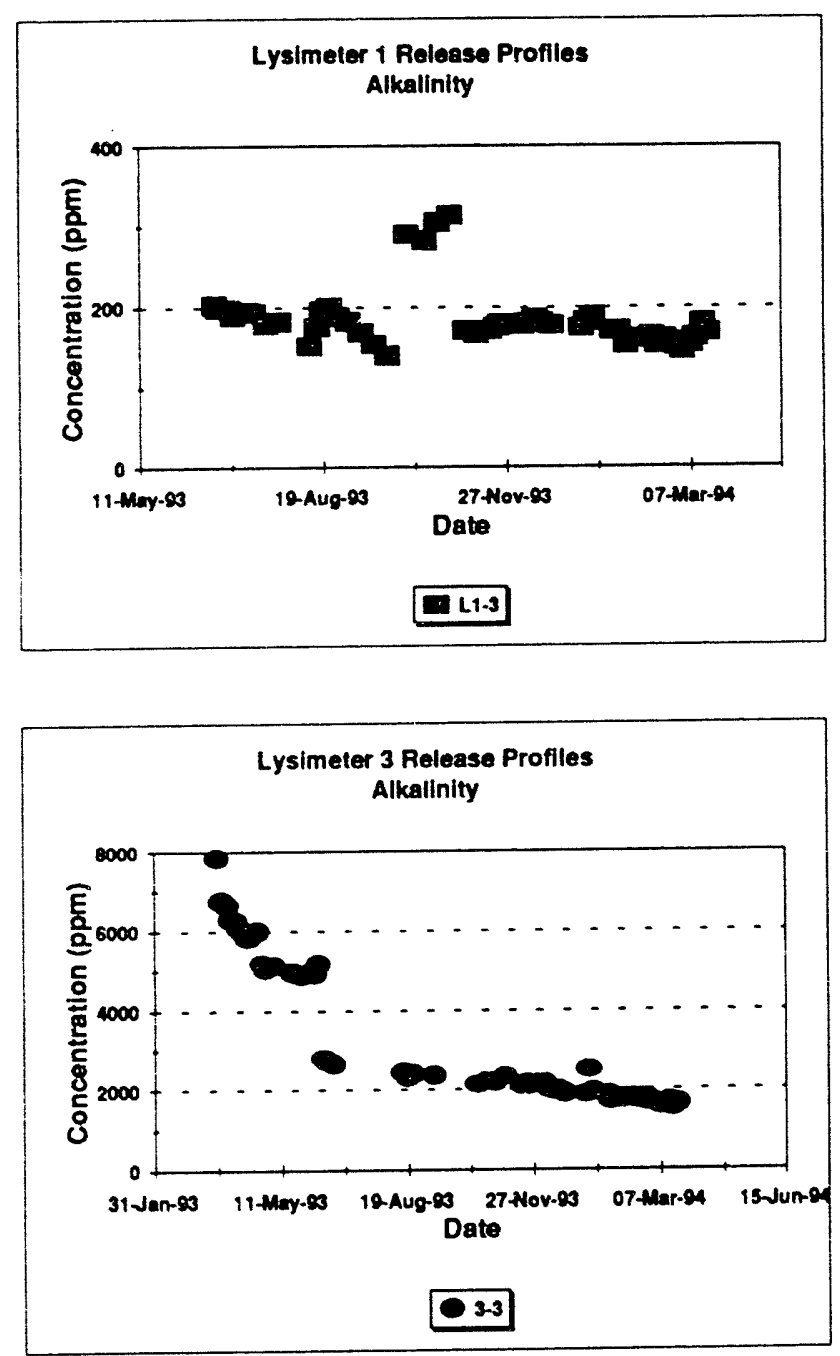
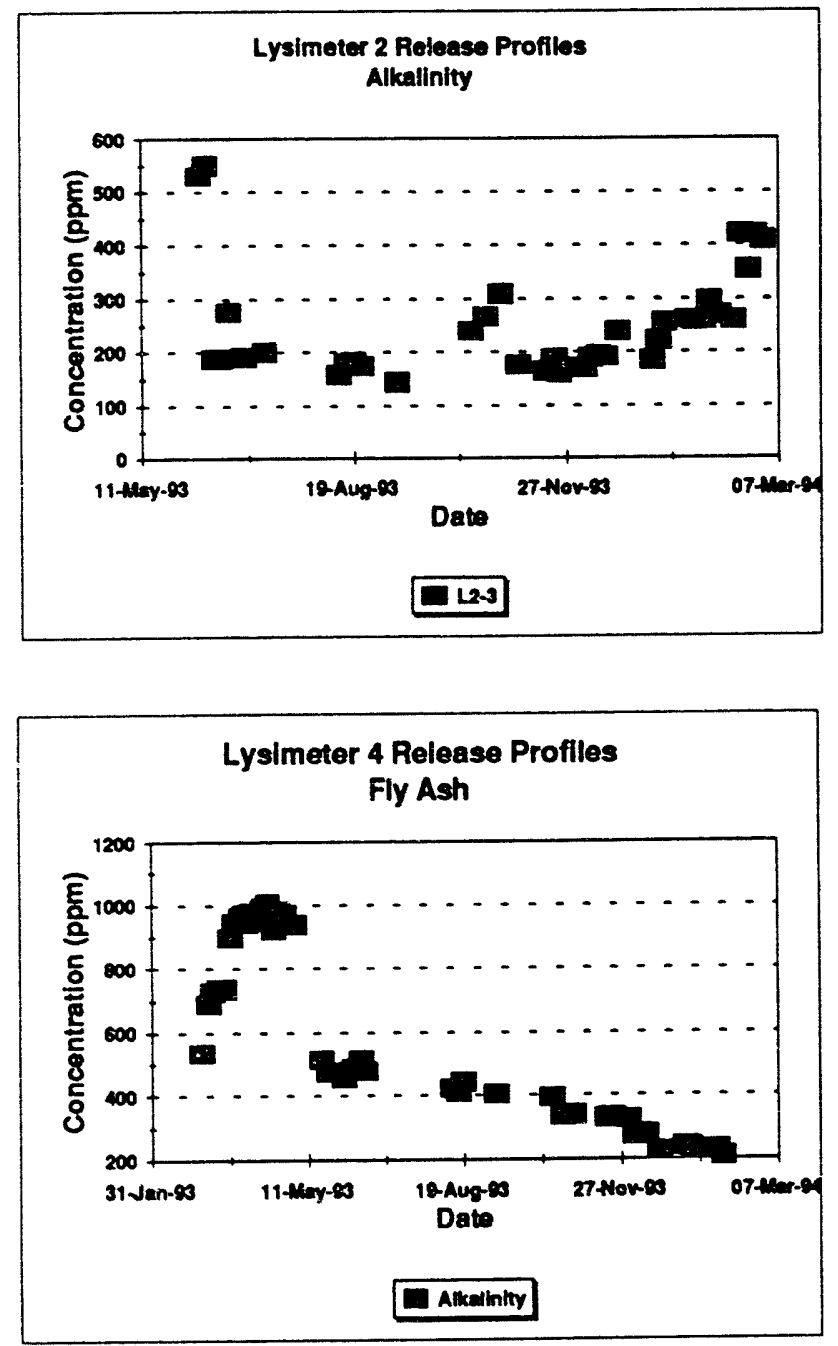

Figure 6 

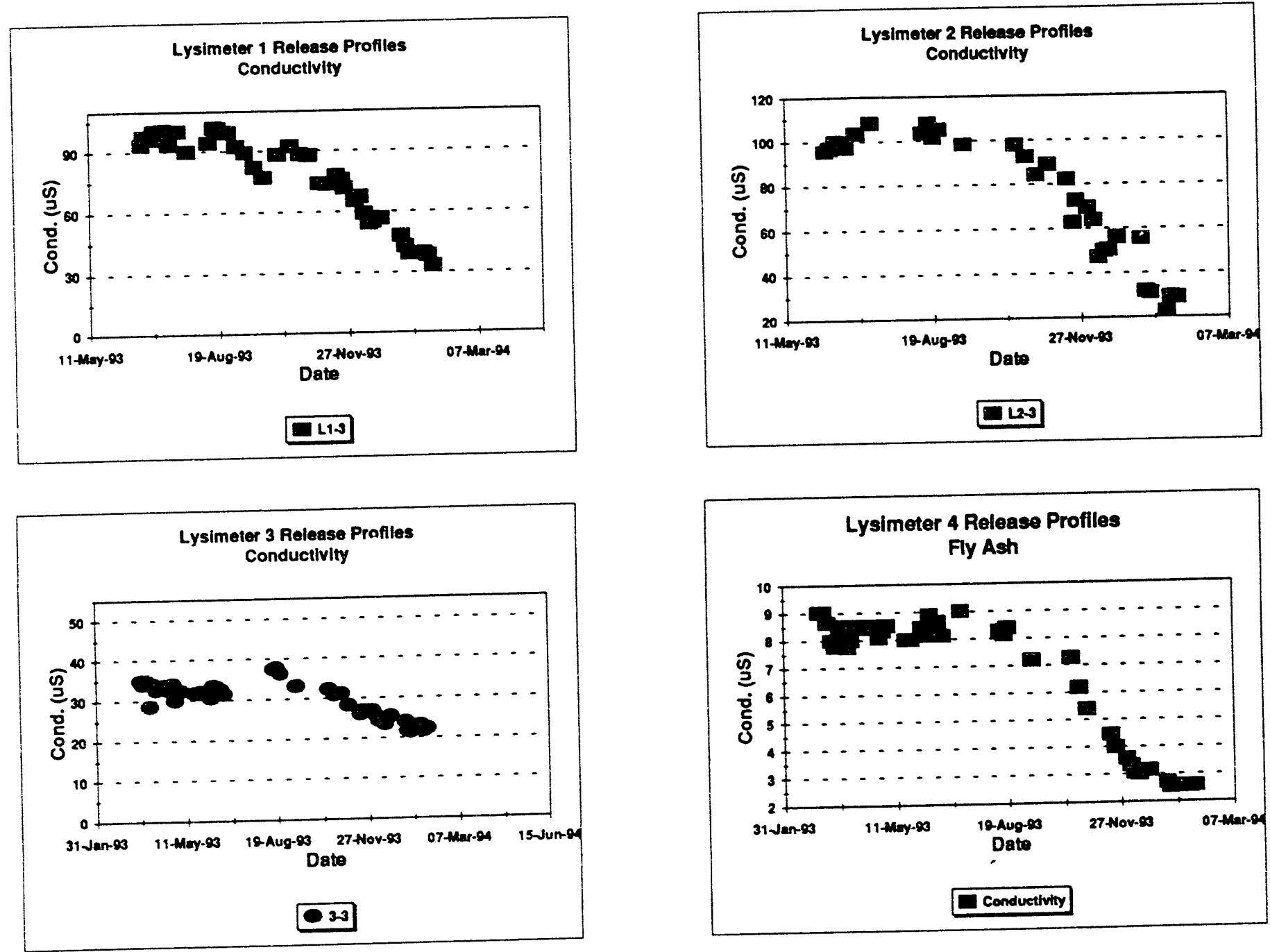

Figure 7 

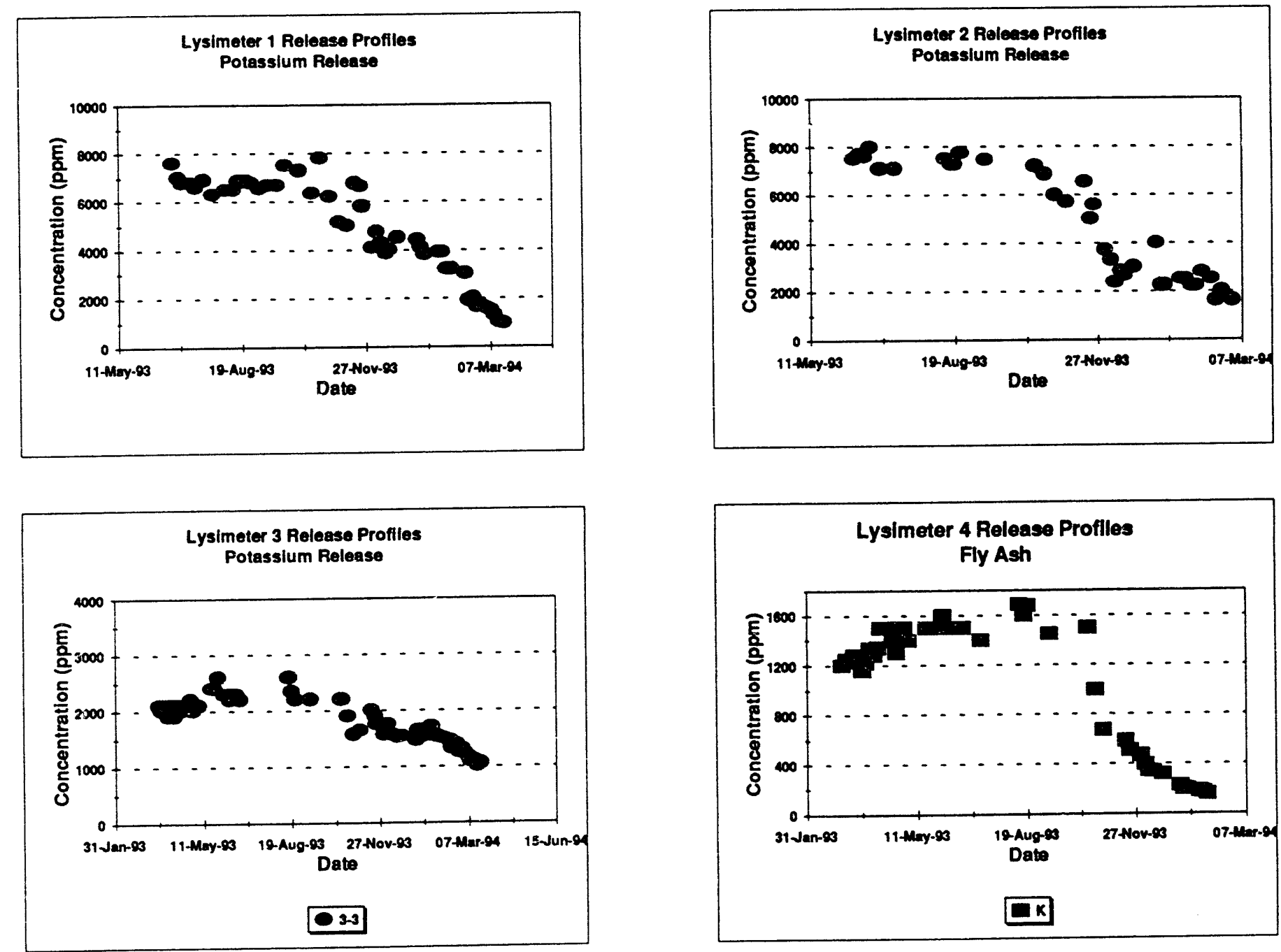

Figure 8 

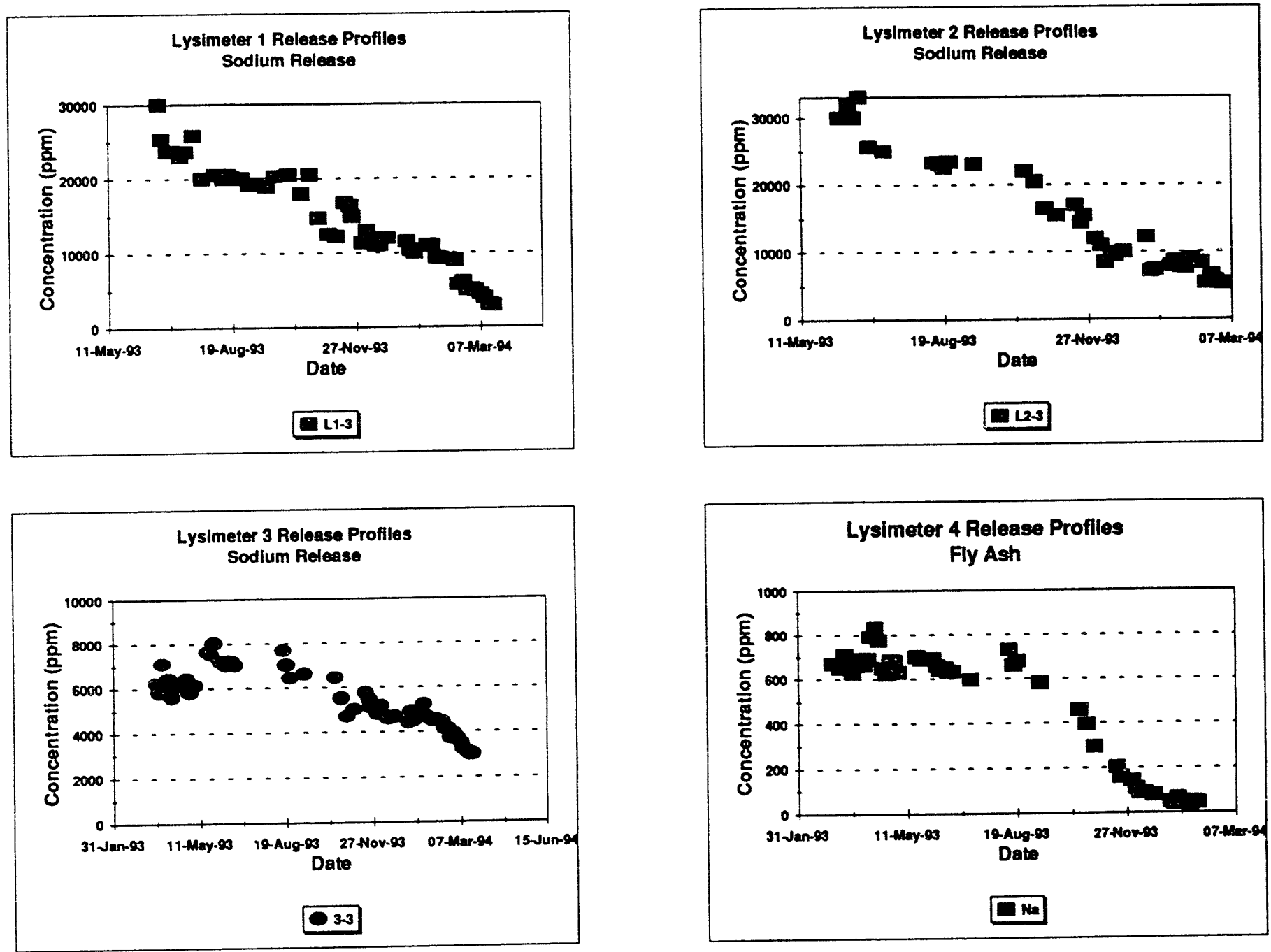

Figure 9 

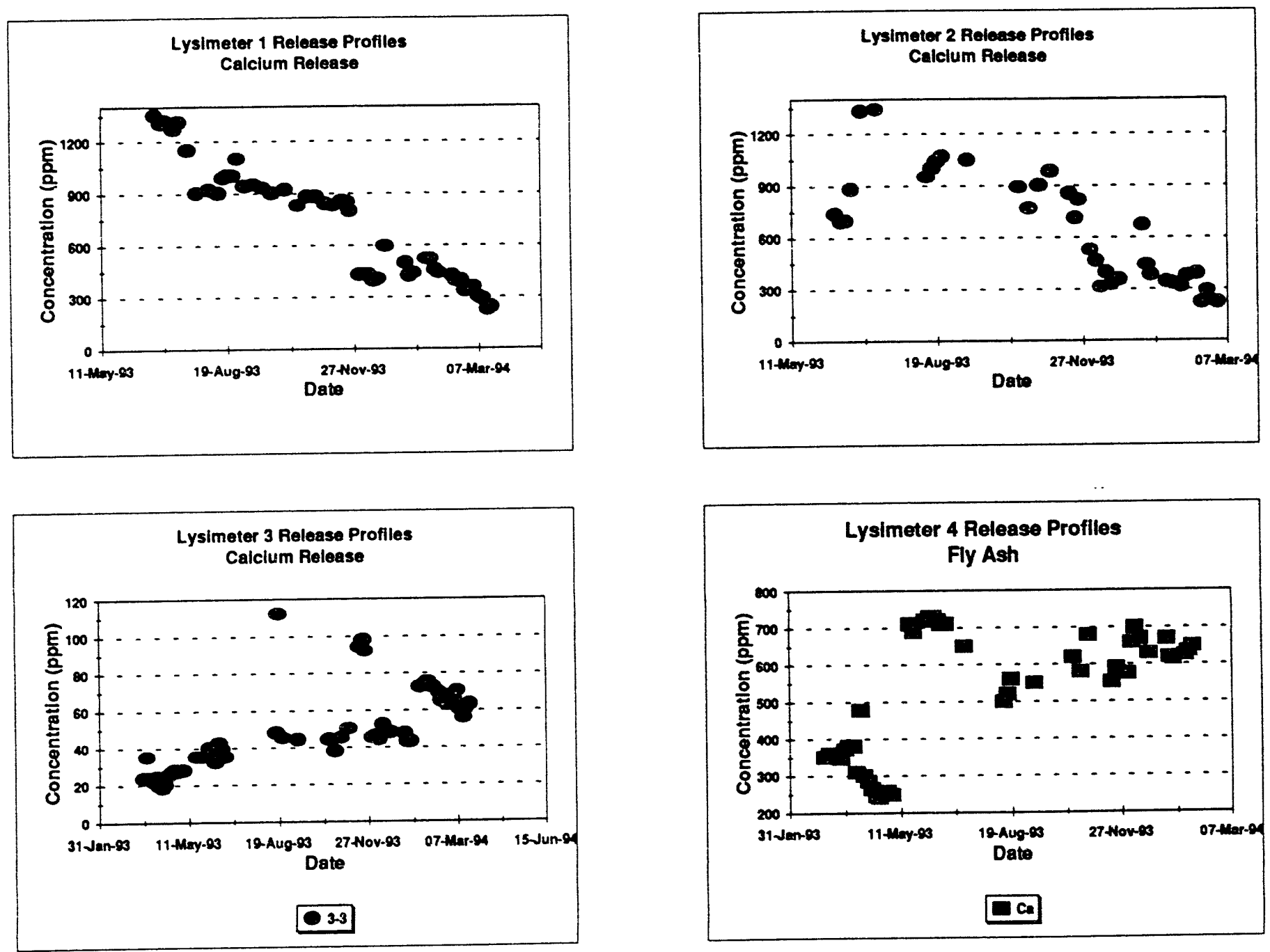

Figure 10 

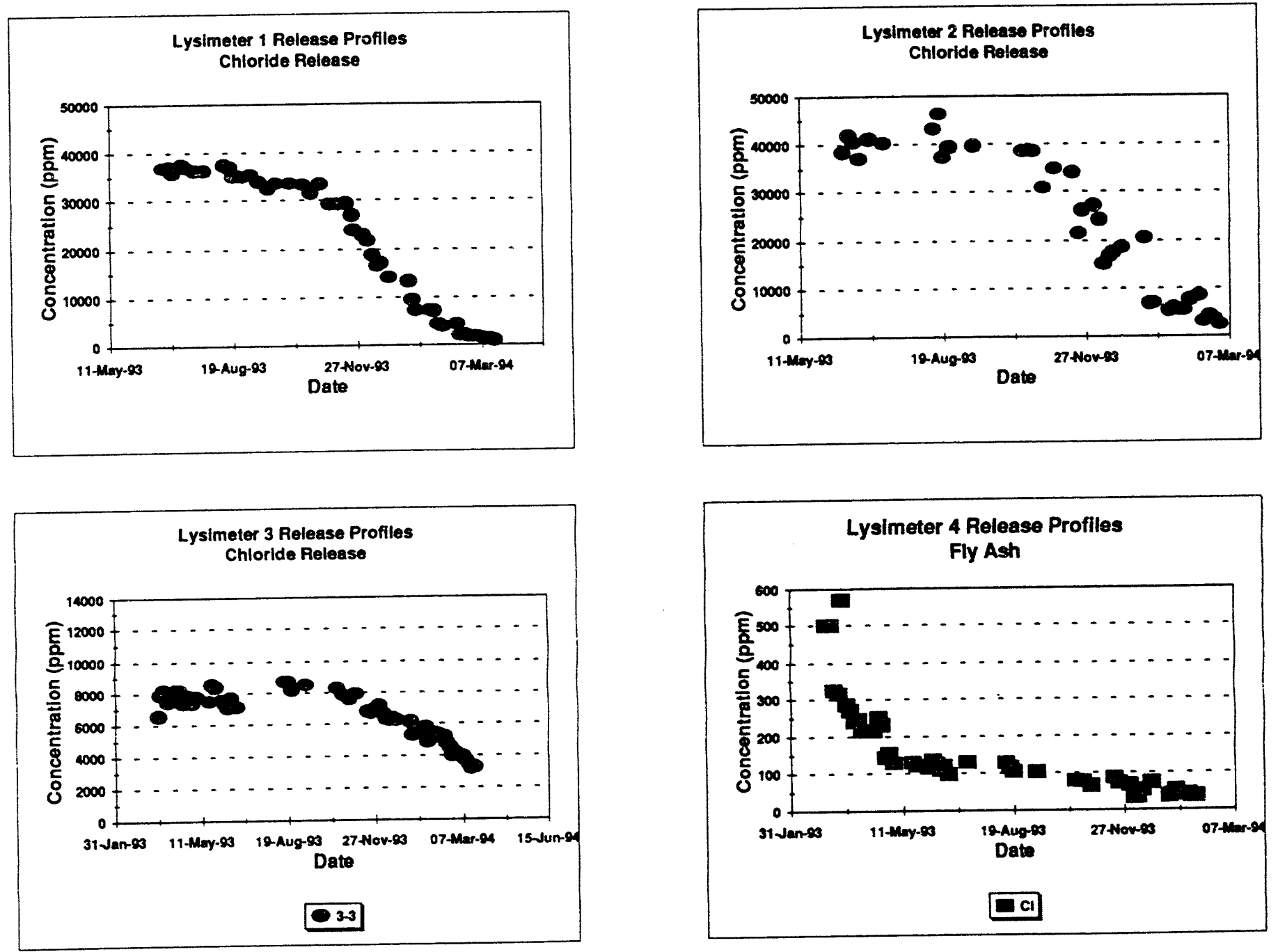

Figure 11 

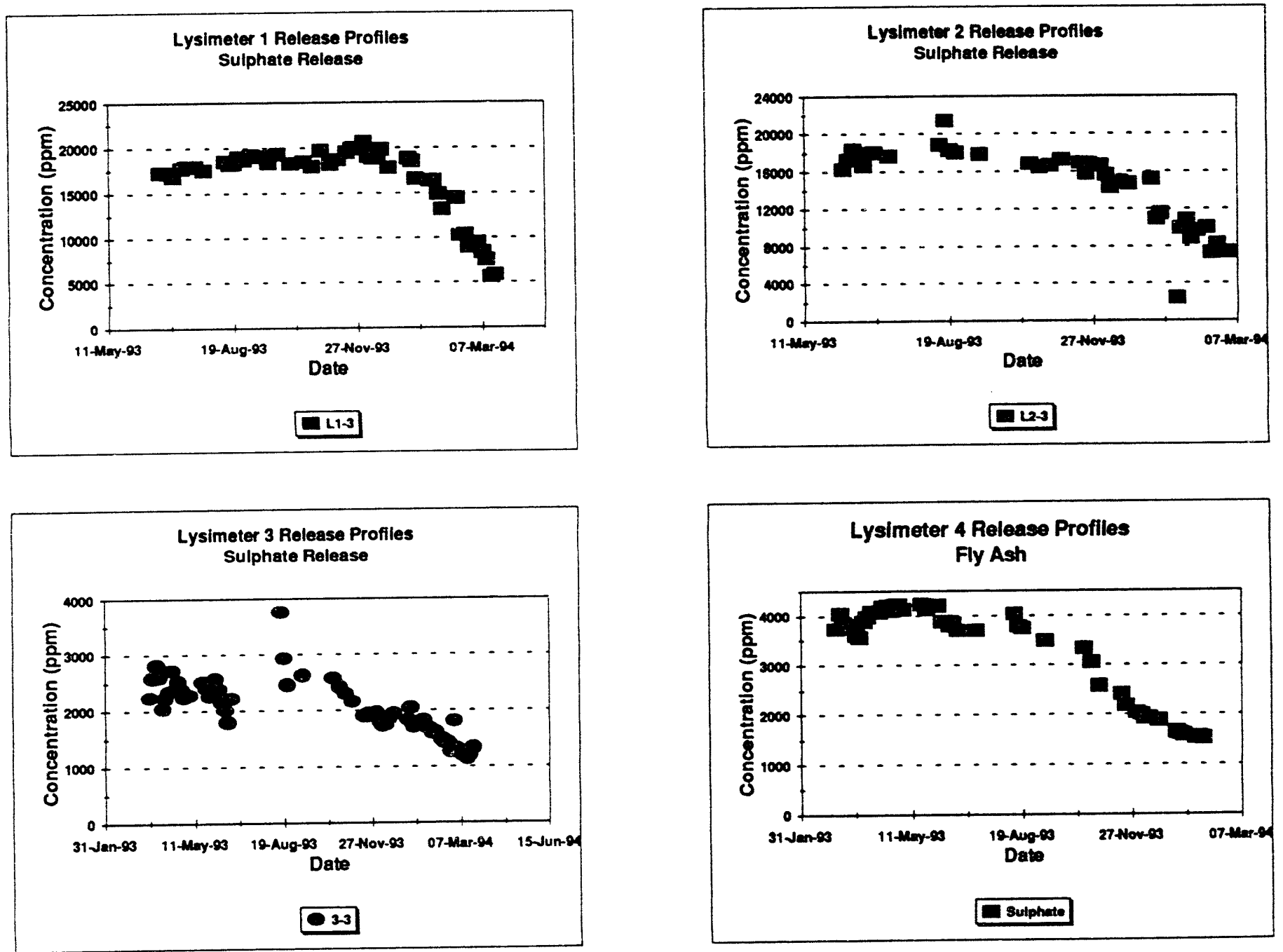

Figure 12 

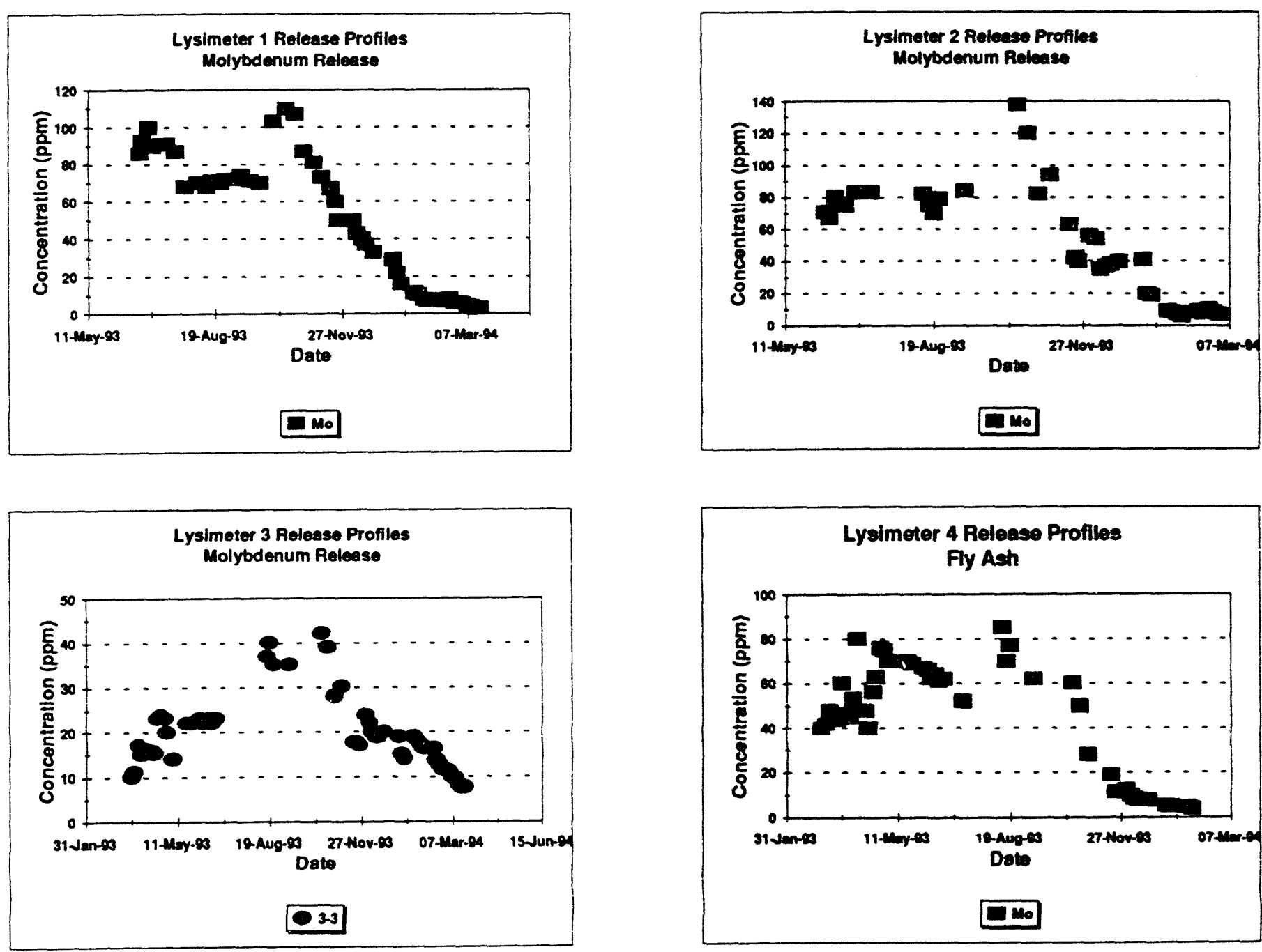

Figure 13 

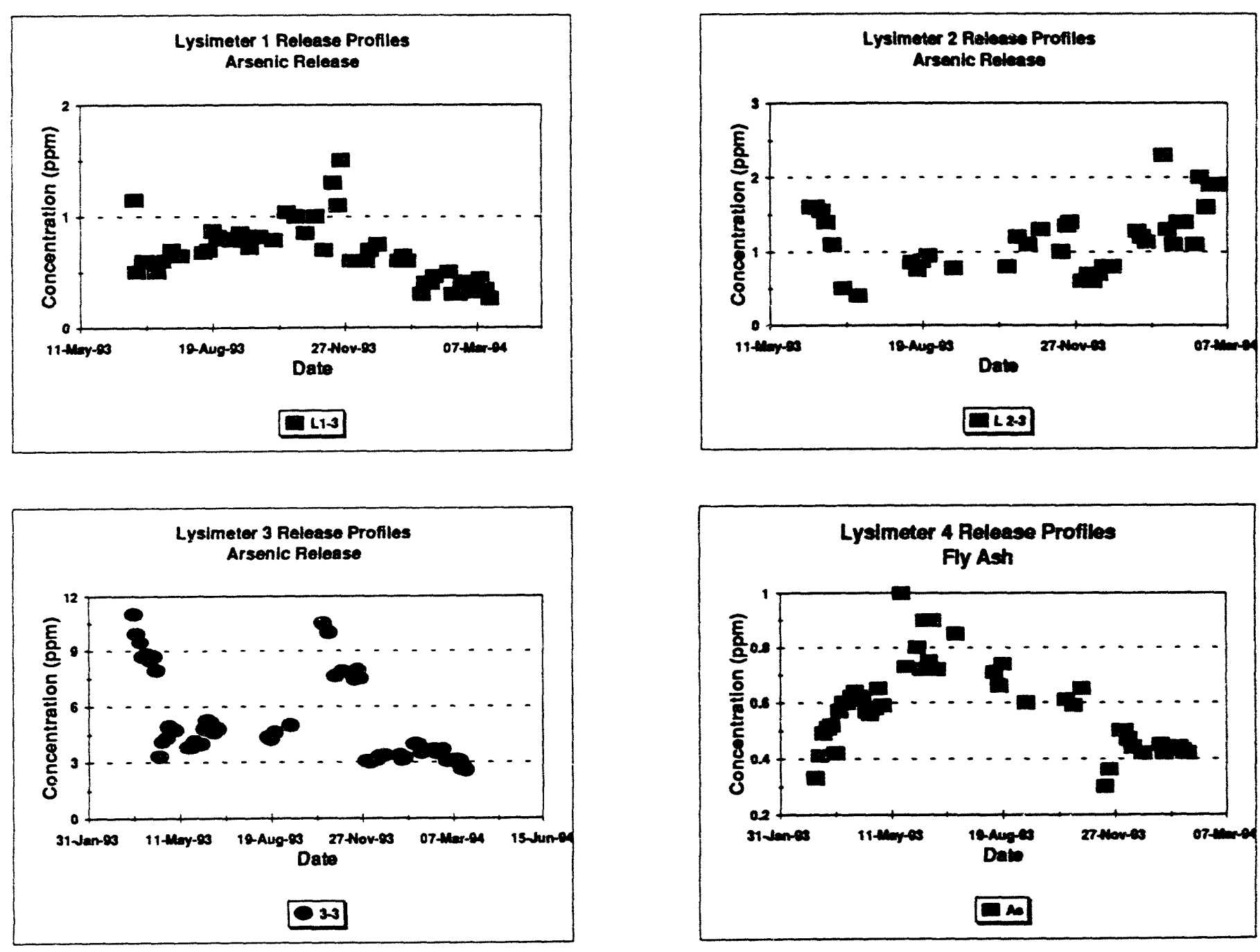

Figure 14 

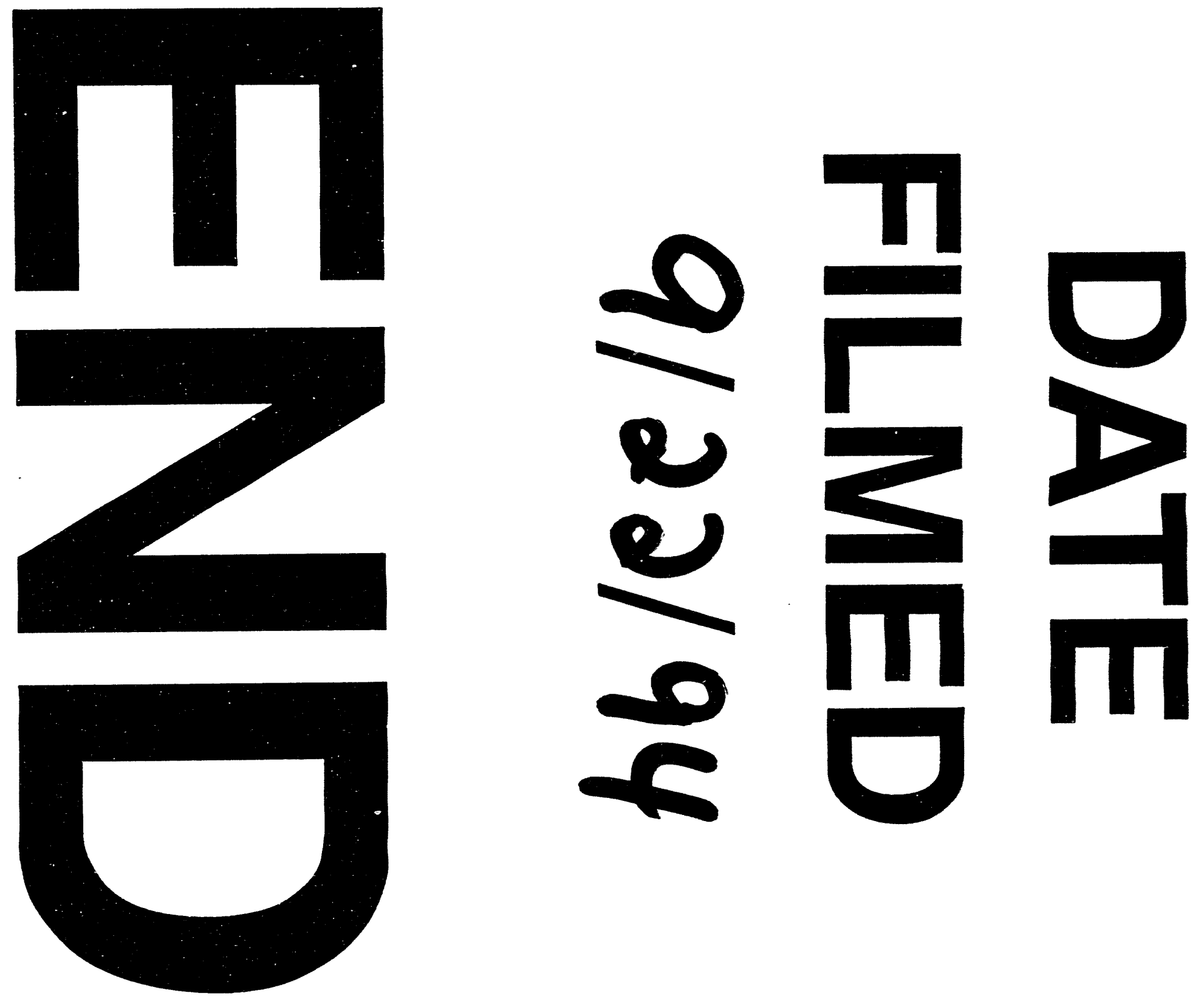
